\title{
Contributions to the Flora of the Red Lake Peatland, Northern Minnesota, with Special Attention to Carex
}

\author{
GERALD A. WHEELER, PAUL H. GLASER, ${ }^{1}$ EVILLE GORHAM, ${ }^{2}$ \\ CLIFFORD M. WETMORE, FRANK D. BOWERS ${ }^{3}$ AND JAN A. JANSSENS ${ }^{1}$ \\ Department of Botany, University of Minnesota, St. Paul 55108
}

\begin{abstract}
The Red Lake Peatland, situated in N-central Minnesota, is the largest continuous mire in the northern portion of the contiguous United States. It consists of a mixture of ombrotrophic bogs and minerotrophic fens organized into a complex of highly distinctive landforms, including open bogs, wooded bogs, Sphagnum lawns, strings, flarks, fen-pools and wooded islands. The bogs are poor in species and occupy acid sites with water poor in mineral salts; the minerotrophic areas are floristically richer and can be divided into poor- and rich-fen sites. Ditching and roadbuilding in certain portions of the peatland have produced drastic changes in the vegetation and landscape as a result of obstructed water tracks flooding upstream and drying out downstream.

The peatland, which occupies a large area of gentle slope and poor drainage, has a flora that is relatively impoverished. In all, 331 plant taxa were recorded from the mire, including 195 vascular plants, 67 bryophytes and 69 lichen taxa. Members of the Cyperaceae account for $23 \%$ of the vascular flora, and the largest genus in the mire is Carex with 29 species. Each landform feature is distinctive in its floristic composition, and the vascular and nonvascular taxa associated with the different physiographic features are discussed.

This paper provides an account of Carex in the peatland and discusses the differential response by members of the genus to gradients of nutrition, shading and hydrology. Some carices grow best under acid conditions, thus frequenting ombrotrophic and poor-fen sites, whereas other species grow best in rich-fen sites. Carex species useful in separating areas of ombrotrophy from those of poor fen are indicated, as are those carices that serve as obligate rich-fen indicators.

The floristic similarities between the Red Lake Peatland and 14 other peatlands in North America and northern Europe are discussed, and the ombrotrophic bog flora of the Red Lake Peatland is compared to the bog floras of the Hudson Bay lowlands and northern Fennoscandia.
\end{abstract}

\section{INTRODUCTION}

The Red Lake Peatland, situated just $\mathrm{N}$ of Upper Red Lake in northern Minnesota, is the largest area of continuous peatland (or mire) in the northern portion of the contiguous United States. Owing to its immense size and general inaccessibility, most of the peatland remained botanically unexplored prior to the present study, which covered the 1978 field season. The major objectives of this investigation were to establish a classification of major vegetation types that could be used for mapping purposes and to catalog the plants of the area.

The studies of Heinselman (1963, 1970), Hofstetter (1969) and Griffin (1975, 1977) supplied most of the botanical knowledge of the area prior to 1978, with Hofstetter's the most important floristically. The present study differs from previous studies in covering a large portion of the interior rather than small areas near the periphery of the peatland. This was made possible by the availability of a helicopter during the field season. In all, 89 sites scattered throughout the major landscape features of the peatland were visited during the study.

\footnotetext{
${ }^{1}$ Limnological Research Center, University of Minnesota, Minneapolis 55455.

2 Department of Ecology and Behavioral Biology, University of Minnesota, Minneapolis 55455 .

${ }^{3}$ Department of Biology, University of Wisconsin, Stevens Point 54481.

This paper is Limnological Research Center Contribution No. 164.
} 
Although information is included to acquaint the reader with the physiography of the study area, the primary objectives of this paper are: (1) to provide an overview of the peatland flora; (2) to discuss the distribution of Carex species along various environmental gradients in the mire, and (3) to discuss the floristic similarities that exist between the Red Lake Peatland and other peatlands in North America and northern Europe. These aspects are not covered in a separate paper (Glaser et al., 1981), which deals with major vegetation types, water chemistry and the factors controlling the development of landscape features.

The classification of peatland vegetation used in this paper makes use of two major types, bog and fen, that were first defined in their present sense by Du Rietz (1949, 1954) and have since been used by Sjörs $(1948,1950,1952,1959,1961,1963)$, Malmer (1962) and others. Bog communities are ombrotrophic, i.e., dependent solely upon atmospheric deposition for their mineral supply, whereas fen communities are minerotrophic, i.e., dependent largely upon water that has percolated through mineral soil. In addition, poor fens are differentiated from rich fens, as proposed by Du Rietz, on the basis of acidity and other chemical properties of surface waters.

\section{PhysiogRAPHY}

The Red Lake Peatland is situated in northeastern Beltrami County and adjacent parts of Koochiching and Lake of the Woods counties. It occupies a large area of gentle slope that was formerly the eastern arm of Glacial Lake Agassiz. The peatland extends ca. $80 \mathrm{~km} \mathrm{E}-\mathrm{W}$ and $15 \mathrm{~km} \mathrm{~N}-\mathrm{S}$, thus covering an area of ca. $1200 \mathrm{~km}^{2}$. Physical characteristics of the region are discussed by Glaser et al. (1981), who also present maps of the area.

The peatland consists of a complex of ombrotrophic bogs and minerotrophic fens, assignable to four main areas or watersheds from W-E: (I) Western area, consisting of a broad-patterned water track; (II) West-central area, a complex of raised bogs, ovoid islands and water tracks; (III) East-central area, a broad-patterned water track leading to the NW, and (IV) Eastern area, a complex of raised bogs and water tracks. These areas have also been called the (I) Great Western Patterned Fen; (II) Divide; (III) Ludlow Patterned Fen, and (IV) Koochiching Raised Bog Area (Wheeler and Glaser, 1979).

The western water track (I), which is approximately $4 \mathrm{~km}$ wide, carries mineralrich water eastward and then northward for a distance of ca. $40 \mathrm{~km}$ to tributaries of the Rapid River. A smaller branch leads S to Upper Red Lake. The minerotrophic water is derived mainly from the mineral soil upland to the $W$, but along the northern edge some additional nutrient-rich water enters from the NW. The water track is for the most part a patterned or ribbed fen composed of watery linear depressions - flarks - alternating with low, sinuous ridges - strings (Sjörs, 1950, 1963)-all oriented at right angles to the water flow. The western water track is studded with small forested islands that are elongated and somewhat raindrop-shaped (Sjörs, 1963) or teardrop-shaped (Heinselman, 1963), being widest at the blunt, upstream end and narrowing to a prolonged tail downstream. Paleoecological information (Griffin, 1977) indicates that the ribbed fen started as a wet meadow about 3000 years ago, as the climate became more pluvial, and that island growth started somewhat later. Island genesis and development are discussed by Glaser et al. (1981). The teardrop islands are minerotrophic like the ribbed fen in which they occur.

Watershed II (Fig. 1) is predominantly an ombrotrophic complex consisting of a large, linear raised bog and several ovoid-shaped islands, the latter of which contain both open and forested bog vegetation. The linear raised bog is centered ca. $3 \mathrm{~km} \mathrm{~N}$ of Upper Red Lake and extends some $6 \mathrm{~km} \mathrm{W-E}$. The central portion of the bog is more or less heavily wooded; the periphery consists of radiating tongues of forested bogs and intervening open bog drains. Similar raised bogs are known elsewhere in Minnesota (Heinselman, 1963, 1970; Finney, 1966) and in the Hudson Bay lowlands (Sjörs, 
1963). The several ovoid-shaped islands to the $\mathrm{N}$, like the linear raised bog, are not influenced by water from mineral soil. The ovoid islands differ from the teardrop-shaped islands of the western water track in being much larger and more bulbous, as well as being definitely ombrotrophic. The ovoid islands are 1-4 km long and 1-2 km wide. In contrast, the teardrop islands are much narrower and the majority of them are less than $800 \mathrm{~m}$ long. Most of the ovoid islands have well-developed trees only along the margins, the centers being predominantly treeless.

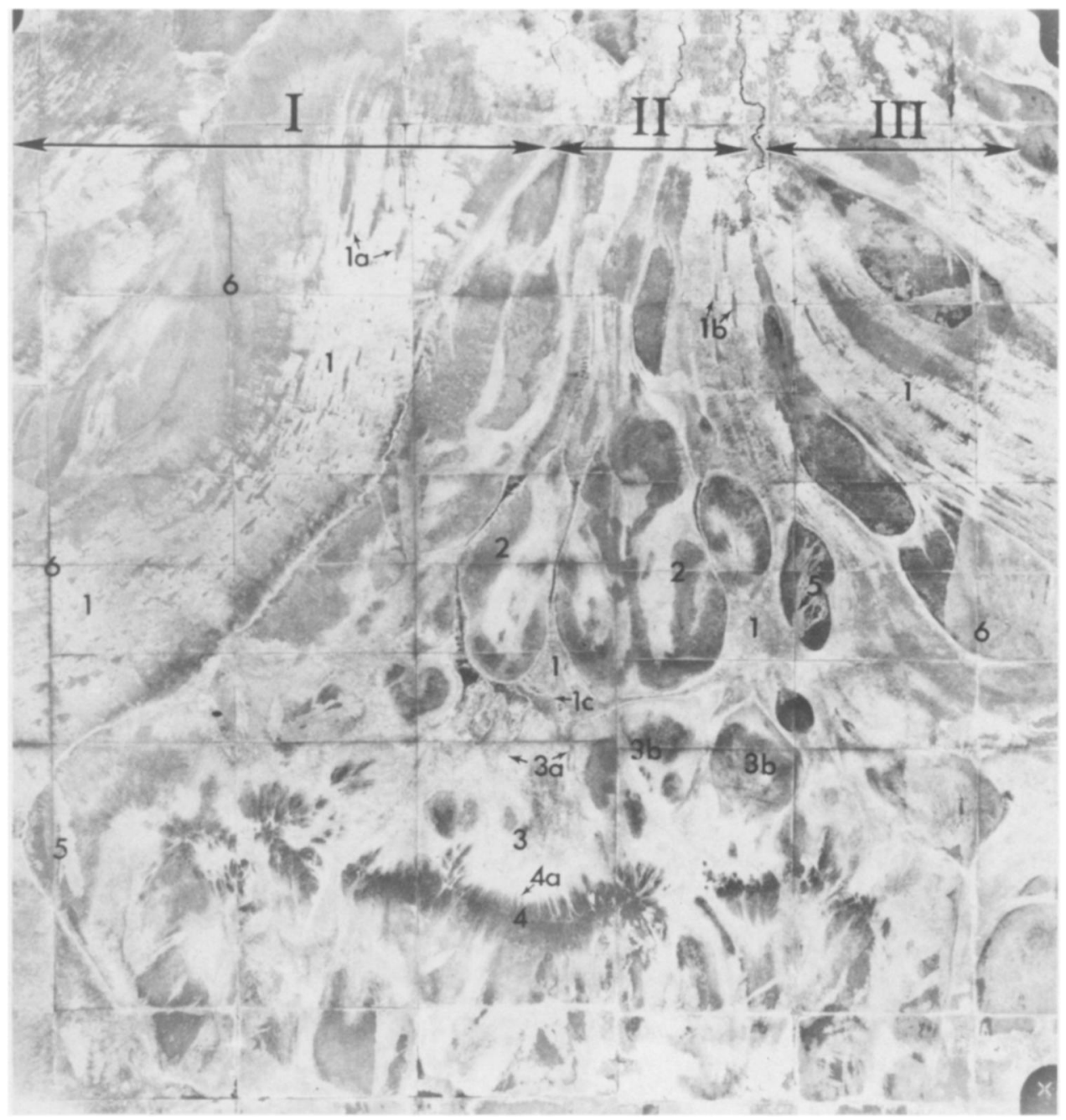

Fig. 1. - Aerial photograph of the W-central watershed of the Red Lake Peatland. Small portions of water tracks from the $\mathrm{W}$ and $\mathrm{E}$-central watersheds are also visible in the uppermost leftand right-hand corners, respectively. The drainage ditches are 1 or 2 miles apart. The following landscape units are labeled: I- western watershed, II-W-central watershed, III-E-central watershed; 1 -patterned fen, 1a-teardrop island, 1b-linear island, 2-ovoid islands (with horseshoe ring of spruce forest), 3-Sphagnum lawn, $3 a-$ incipient water track, $3 b$-incipient ovoid island, 4 -raised bog forest, $4 \mathrm{a}$-bog drain, 5-fire scar, 6 -drainage ditch. The inferred direction of water flow is from the lower portion of the photograph toward the upper portion 
The ovoid islands, which are somewhat attenuated downslope to the $\mathrm{N}$, are sharply bounded by water tracks that are extremely narrow but nevertheless still display the ribbed fen pattern. Occasionally, unvegetated areas of open water or fen-pools are present in these water tracks. The narrow water tracks appear to originate and run $\mathrm{N}$ from the ombrotrophic bog drains of the linear raised bog. However, a little to the $\mathrm{S}$ of the ovoid islands the chemical characteristics of their waters change radically and come to resemble those of minerotrophic fens by some means as yet not understood.

Lying between the linear raised bog and the group of ovoid islands is a large, open, meadow-like area that appears where bog drains from the raised bog coalesce northward. This open area extends ca. $3 \mathrm{~km} \mathrm{S-N}$ and $10 \mathrm{~km} \mathrm{W-E.} \mathrm{At} \mathrm{its} \mathrm{northern} \mathrm{margin,}$ and immediately $\mathrm{S}$ of the ovoid islands, are several small forested islands, most of which are circular in shape. Although situated in a portion of the peatland that is predominantly ombrotrophic in nature, surface waters taken from the meadow-like area and the small circular islands reveal them to be weakly minerotrophic.

Watershed III lies just E of II and is somewhat curved. The flow of water in the fen is at first from E-W, but as it approaches area II it curves northward to the Rapid River. Like the western water track, area III is marked by alternating flarks and strings. Some of the forested islands occurring at its downslope margin are narrow and elongate rather than teardrop-shaped. The area is traversed by a major N-S highway, the only one that has been constructed through the mire.

Watershed IV forms the northeastern portion of the peatland. Like area II, it is predominantly an area of ombrotrophic bogs. It contains a variety of raised bogs as well as a few ovoid islands sharply bounded by narrow water tracks. These water tracks locally contain large fen-pools and do not display the ribbed pattern as well as do most of the other fens in the peatland.

Several miles of drainage ditches were dug in the peatland area between 1900 and 1918 in preparation for agriculture (Hofstetter, 1969). After the agrarian project failed, however, ditching was halted. The ditches were constructed along N-S and E-W section lines and were placed 1 or 2 miles apart. Drainage ditches are common in areas II and III, less so in I and IV.

\section{Chemistry of Surface Waters}

Data on water chemistry are presented elsewhere (Glaser et al., 1981). The surface waters of the peatland range from very acid bog waters (minimum $p \mathrm{H} \mathrm{3.8)}$ ) to circumneutral fen waters (maximum $p \mathrm{H}$ 6.9). Specific conductivity (minus that ascribable to hydrogen ions, see Sjörs, 1952) is a measure of salt content and is low in all peatland waters. Bog waters are most dilute, with a minimum conductivity of 12 $\mu$ mhos; fen waters are more concentrated, exhibiting a maximum conductivity of 128 $\mu$ mhos.

The major factor increasing the salt content of minerotrophic fen water over that of ombrotrophic bog water is calcium bicarbonate leached from mineral soil. Bog waters are low in calcium (minimum $0.5 \mathrm{mg} / \mathrm{liter}$ ) and fen waters are high (maximum 19.6 $\mathrm{mg} / \mathrm{liter}$ ).

Light extinction (measured in a $1-\mathrm{cm}$ cell at $320 \mathrm{~nm}$ with a corex filter) in general reflects the degree of stagnation of the peatland waters, because where water moves slowly it tends to accumulate large amounts of dissolved organic matter that absorbs strongly in the ultraviolet. The acid bog waters are generally highly colored and slowmoving, especially in those sites where they do not reach the peat surface and must be sampled from pits dug in the peat. In such sites light extinction may exceed 2 units. The fen waters move more swiftly in their water tracks and are sometimes very clear indeed, with extinction values as low as 0.1 unit. 
genera in 50 families (Table 1). Among the nonvascular plants, 61 bryophyte taxa (49 mosses and 12 hepatics) and 69 lichen taxa were recorded. In addition, six species of Sphagnum reported from the peatland by Hofstetter (1969) are included in this report, although they were not found during the 1978 study. In all, 331 taxa are presently known from the Red Lake Peatland, in contrast to the 171 previously reported (Hofstetter, 1969). This total includes taxa growing in the peatland proper, in the partially dried-up fens adjacent to the N-S highway, and along the margins of drainage ditches in the interior. Taxa not included are those growing on upland sites in mineral soil, on wooded spoil banks near the highway, in marginal communities, and along roadsides and adjacent embankments.

Of the vascular plants (Wheeler and Glaser, 1982b), members of the Cyperaceae make up $23 \%$ of the taxa; Carex alone makes up $15 \%$. The next largest family, the Asteraceae, makes up 8\%. The Asteraceae with eight genera and the Cyperaceae, Poaceae and Orchidaceae with seven genera each are the families with the largest representation. The largest genus is Carex, with 29 taxa represented. Eight of the taxa found in the peatland are considered rare in Minnesota: Carex exilis, Cladium mariscoides, Drosera anglica, D. linearis, Juncus stygius var. americanus, Rhynchospora fusca, Pogonia ophioglossoides forma albiflora and Xyris montana (Wheeler and Glaser, 1979).

Unfortunately, the amount of time spent collecting nonvascular plants was less than that given to the collection of vascular plants. Therefore, while the writers believe that the overall list given for the vascular plants (Tables 2-5) is nearly complete, the lists for bryophytes (Table 6) and lichens (Table 7) are not. We do believe, however, that all lists are complete in regard to those plants that are of major importance to the development of the peatland. In Tables 2-5 the vascular plants have been categorized according to their association with specific landscape features. But because for many of the nonvascular plants their exact status in the mire is still not clear, no such separation has been attempted for them in Tables 6 and 7 .

The vascular plants were collected by GAW and PHG; one of us (GAW) takes full responsibility for these identifications. The lichens were collected and identified by CMW, and all lichen records have been computerized for future retrieval. The majority of the bryophytes were collected by FMB and GAW, but critical collections were also made by EG and PHG. The bryophytes were identified by FMB and JAJ. All of the above-mentioned specimens will eventually be housed at the University of Minnesota Herbarium. Specimens of the six species of Sphagnum reported by Hofstetter (1969) that are included in Table 6 of this report (indicated as such by an asterisk) are on deposit at the University of Minnesota Herbarium.

Authorities and nomenclature for the vascular plants follow Fernald (1970), except that Carex spp. follow Wheeler (1981). Crum et al. (1973) were followed for the mosses, except that Sphagnum spp. and Polytrichum juniperinum var. affine follow Crum (1976). Stotler and Crandell-Stotler (1977) were used for the hepatics; and Hale and Culberson (1970) for the majority of the lichens.

TABLE 1.- Major groups of vascular plants in the Red Lake Peatland

\begin{tabular}{lccccc}
\hline & \multicolumn{3}{c}{ Taxa } & & \\
\cline { 2 - 4 } Vascular & Native & $\begin{array}{l}\text { Intro- } \\
\text { duced }\end{array}$ & Total & Genera & Families \\
plant group & 7 & 0 & 7 & 6 & 3 \\
\hline Pteridophytes & 4 & 0 & 4 & 4 & 2 \\
Gymnosperms & 81 & 0 & 81 & 32 & 12 \\
Monocotyledons & 101 & 2 & 103 & 62 & 33 \\
Dicotyledons & 193 & 2 & 195 & 104 & 50 \\
$\quad$ Total & & &
\end{tabular}




\section{Vegetation in Relation to Landscape Features and Water Ghemistry}

CHARACTERISTICS OF SPECIES RICHNESS AND WATER CHEMISTRY

The vegetation of the Red Lake Peatland can be separated into bog and fen, a division based on species richness and surface-water chemistry. The communities of the bogs, which characterize areas II and IV, are distinguished by low species richness. These communities occupy sites the surface waters of which are acid and poor in mineral salts (resulting in low specific conductivity). But because of the relatively stagnant nature of the bog waters, they are rich in dissolved organic matter which imparts a brown color (resulting in high light extinction).

Twenty-three vascular taxa are known from ombrotrophic sites in the peatland (Table 2). None of these is an ombrotrophic indicator, however, because each of them also occurs on minerotrophic sites, at least in poor fen.

The communities of the rich fens, so characteristic of the broad water tracks in areas I and III and the narrow water tracks that separate ovoid islands in areas II and IV, are distinguished from those of the bogs by the following: higher species richness, lower acidity, higher values for calcium and specific conductivity, and waters that are poor in dissolved organic matter (resulting in low light extinction) because they are generally moving instead of stagnant.

In addition to the bog and rich-fen areas, there are areas in the peatland where minerotrophy is clearly weak. Such weak minerotrophy exists in the meadow-like extensions of bog drains and in the narrow ecotones that lie between bogs and fens. Some wooded islands in area II and III are also best included here. Similar areas of weak minerotrophy are known from the Hudson Bay lowlands and have been called poor fen (Sjörs, 1963). Poor-fen areas typically harbor bog species and some indicators of minerotrophy.

Of the 195 vascular taxa recorded from poor- and rich-fen sites, 172 were not found on ombrotrophic sites. Of the latter, 80 occur either on strings or in flarks (and/or on the edges of fen-pools) and are listed in Table 3. Table 4 lists 47 taxa that occur on minerotrophic islands but that were found neither in bogs nor in open portions of fens. Table 5 lists 45 taxa that are restricted to disturbed sites - partially dried-up fens and the margins of drainage ditches. It is important to note, however, that many of the taxa occurring in bogs also frequent open fens, wooded islands and disturbed sites; and many taxa present in open fens also occur on wooded islands and in disturbed sites.

SPECIES ASSOCIATED WITH LANDSCAPE FEATURES

Each of the physiographic features in the Red Lake Peatland is distinctive in its floristic composition. Indeed, in the mire there exists such a delicate relationship between plants and their moisture and chemical tolerances that only slight variations in these parameters result in different vegetation patterns.

TABLE 2. - Vascular species occurring in ombrotrophic bogs. These taxa also occur on other landscape features in the peatland

Open and wooded bogs

Andromeda glaucophylla Link, Carex pauciflora Lightf., Chamaedaphne calyculata (L.) Moench, Drosera rotundifolia L., Eriophorum spissum Fern., E. virginicum L., Kalmia polifolia Wang., Larix laricina (Du Roi) K. Koch, Ledum groenlandicum Oeder, Picea mariana (Mill.) BSP, Sarracenia purpurea L., Vaccinium oxycoccos $\mathrm{L}$.

Carex oligosperma Michx.

$$
\text { Open bogs (strongly preferential) }
$$

Wooded bogs (strongly preferential)

Arceuthobium pusillum Peck, Carex paupercula Michx., C. trisperma Dew., Cypripedium acaule Ait., Gaultheria hispidula (L.) Bigel., Listera cordata (L.) R. Br., Monotropa uniflora L., Smilacina trifolia (L.) Desf., Vaccinium myrtilloides Michx., V. vitis-idaea L. var. minus Lodd. 
Open bog. - The ombrotrophic areas of the peatland can be divided into linear raised bogs and ovoid islands. As pointed out earlier, most ovoid islands in the $\mathrm{W}$-central area (II) have trees only along their margins whereas the centers are predominantly open. The floristic composition of the central open areas differs significantly from that of the marginal forested areas. The higher plants of the open bogs are almost invariably dominated by Carex oligosperma. Along with this sedge, other vascular species consistently present are Chamaedaphne calyculata, Eriophorum spissum, Kalmia polifolia, Sarracenia purpurea, Ledum groenlandicum, Andromeda glaucophylla, and less commonly Drosera rotundifolia, Eriophorum virginicum and Carex pauciflora. A few trees of Picea mariana and Larix laricina are usually present in the open bogs, but they tend to be widely scattered and stunted, seldom reaching $6 \mathrm{~m}$ in height.

In open bogs, Sphagnum communities play a very conspicuous and important role, with hummocks usually displaying a vertical zonation of species. Several workers (Moss, 1953; Rose, 1953; Ratcliffe and Walker, 1958; Spearing, 1972; Andrus, 1974; Vitt et al., 1975b; Vitt and Slack, 1975; Judd, 1980) have discussed the vertical distribution of mosses on hummocks; clearly, a strong correlation exists between the galacturonic acid content (and thus cation-exchange capacity) of individual species and optimum height above the water table, with the uppermost species almost invariably having greater amounts than the lower ones (Spearing, 1972).

In open bogs of the Red Lake Peatland, a common vertical arrangement of species on hummocks is, from top to bottom, Sphagnum fuscum, $S$. capillifolium var. tenellum, $S$. magellanicum and $S$. recurvum var. brevifolium. But several variations can be observed.

TABLE 3. - Vascular species occurring in open minerotrophic fens. These taxa are not present in ombrotrophic bogs but, besides frequenting open fens, many of them also occur on the teardrop islands, in partially dried-up fens, and along the margins of drainage ditches

\section{Flarks and fen-pools}

Calla palustris L., Carex buxbaumii Wahlenb., C. chordorrhiza L. f., C. interior Bailey, C. lasiocarpa Ehrh. var. americana Fern., C. leptalea Wahlenb., C. limosa L., C. livida (Wahlenb.) Willd. var. radicaulis Paine, C. rostrata Stokes var. utriculata (Boott) Bailey, Cladium mariscoides (Muhl.) Torr., Drosera anglica Huds., D. intermedia Hayne, D. linearis Goldie, Dulichium arundinaceum (L.) Britt., Eleocharis compressa Sulliv., Equisetum fluviatile L., Eriophorum angustifolium Honckeny, E. gracile Koch, E. tenellum Nutt., E. viridi-carinatum (Engelm.) Fern., Juncus canadensis J. Gay, J. pelocarpus Mey., J. stygius L. var. americanus Buchenau, Menyanthes trifoliata L., Phragmites communis Trin. var. berlandieri (Fourn.) Fern., Pogonia ophioglossoides (L.) Ker, P. ophioglossoides (L.) Ker forma albiflora Rand \& Redfield, Potamogeton gramineus L., Potentilla palustris (L.) Scop., Rhynchospora alba (L.) Vahl., R. fusca (L.) Ait. f., Scheuchzeria palustris L. var. americana Buchenau, Scirpus hudsonianus (Michx.) Fern., S. validus Vahl., Triglochin maritima L., Typha latifolia L., Utricularia cornuta Michx., U. intermedia Hayne, U. minor L., Xyris montana Ries.

\section{Strings}

Agrostis scabra Willd., Arethusa bulbosa L., Aster junciformis Rydb., A. umbellatus Mill. var. pubens Gray, Betula pumila L. var. glandulifera Regel, Bromus ciliatus L., Campanula aparinoides Pursh, Carex canescens L., C. cephalantha (Bailey) Bickn., C. exilis Dew., C. tenuiflora Wahlenb., Cirsium muticum Michx., Cornus stolonifera Michx., Dryopteris cristata (L.) Gray, Epilobium leptophyllum Raf., Eriophorum chamissonis C. A. Meyer, Galium labradoricum Wieg., Habenaria lacera (Michx.) Lodd., Hypericum virginicum L. var. fraseri (Spach) Fern., Iris versicolor L., Liparis loeselii (L.) Rich., Lobelia kalmii L., Lycopus uniflorus Michx., Malaxis unifolia Michx., Muhlenbergia glomerata (Willd.) Trin., Parnassia palustris L. var. neogaea Fern., Pedicularis lanceolata Michx., Potentilla fruticosa L., Rhamnus alnifolia L'Her., Rubus acaulis Michx., R. pubescens Raf., Salix pedicellaris Pursh var. hypoglauca Fern., Scirpus cespitosus L. var. callosus Bigel., Scutellaria epilobiifolia Hamilt., Senecio pauperculus Michx., Solidago canadensis L., S. uliginosa Nutt., Thelypteris palustris Schott var. pubescens (Lawson) Fern., Trientalis borealis Raf., Viola pallens (Banks) Brain. 
Sphagnum capillifolium var. tenellum and Polytrichum juniperinum var. affine often occupy hummock tops, and in yet other instances lichens, particularly Cladonia spp., invade Sphagnum fuscum communities. Lower on the sides of hummocks, Aulacomnium palustre, Pleurozium schreberi and Dicranum undulatum are often present, and on disturbed and eroded hummocks Mylia anomala is rather common. In wetter portions of the open bogs Sphagnum recurvum var. tenue and, less commonly, $S$. papillosum occur, mostly as low flat mats.

Lichen communities are scattered throughout the open bogs and are usually most abundant on the sides of hollows, particularly those that harbor island-like clumps of trees. Cladonia mitis and $C$. rangiferina are most common, but other species such as $C$. cristatella and $C$. verticillata are locally abundant.

No direct evidence exists for cyclic succession as a feature of the Red Lake Peatland; however, lichen and Polytrichum invasion of Sphagnum hummocks does take place and small clumps of Picea mariana and Larix laricina invariably grow around depressions where Sphagnum once grew. But as Vitt et al. (1975b) point out, in Michigan such island-like clumps of trees seem to be self-perpetuating and are not necessarily subject to cyclic disappearance and regeneration. Hummock-hollow regeneration in bogs has been discussed by Tansley (1939), Moss (1953), Osvald (1970) and Vitt et al. (1975b).

Wooded bog. - In the Red Lake Peatland, the marginal forested bogs of the ovoid islands are dominated by Picea mariana, with scattered trees of Larix laricina also present. Many of the trees are infected by Arceuthobium pusillum with some displaying large witches' brooms. The majority of the vascular species that grow in open bogs also grow in the marginal forested bogs, but Carex oligosperma is conspicuously absent from the latter. Furthermore, Carex trisperma, Vaccinium vitis-idaea var. minus, Gaultheria hispidula, Cypripedium acaule, Monotropa uniflora and Smilacina trifolia are frequent to common in wooded bogs but are rare or absent from the open bogs.

TABLE 4. - Vascular species occurring on minerotrophic wooded islands. These taxa neither frequent ombrotrophic bogs nor the open portions of minerotrophic fens but, besides frequenting wooded islands, some of them also occur in partially dried-up fens and along the margins of drainage ditches

\section{Hummocks}

Amelanchier humilis Wieg. var. compacta Niels., Aronia melanocarpa (Michx.) Spach, Aster puniceus L., Athyrium filix-femina (L.) Roth. var. michauxii (Spreng.) Farwell, Carex brunnescens (Pers.) Poir. var. sphaerostachya (Tuckerm.) Kükenth., C. disperma Dew., Cinna latifolia (Trin.) Griseb., Cornus canadensis L., C. rugosa Lam., Dryopteris spinulosa (O. F. Müll.) Watt, Eupatorium maculatum L., E. perfoliatum L., Geum aleppicum Jacq. var. strictum (Ait.) Fern., Gymnocarpium dryopteris (L.) Newm., Lonicera oblongifolia (Goldie) Hook., L. villosa (Michx.) R. \& S. var. solonis (Eaton) Fern., Maianthemum canadense Desf., Osmunda cinnamomea L., Petasites sagittatus (Pursh) Gray, Polygonum sagittatum L., Populus tremuloides Michx., Pyrola asarifolia Michx. var. purpurea (Bunge) Fern., P. secunda L. var. obtusata Turcz., Rubus strigosus Michx., Salix bebbiana Sarg., S. candida Fluegge, S. discolor Muhl., S. pyrifolia Anderss., Solidago graminifolia (L.) Salisb., Sonchus arvensis L. var. glabrescens Guenth., Grab. \& Wimm., Stellaria longifolia Muhl., Thuja occidentalis L., Vaccinium angustifolium Ait., Viburnum trilobum Marsh, Viola incognita Brain.

\section{Hollows}

Calamagrostis canadensis (Michx.) Beauv., C. neglecta (Ehrh.) Gaertn., Caltha palustris L., Carex diandra Schrank, C. pseudo-cyperus L., Cicuta bulbifera L., Lysimachia thyrsiflora L., Myrica gale L., Potamogeton natans L., Ranunculus gmelini DC. var. hookeri (D. Don) Benson, Rumex orbiculatus Gray, Sparganium minimum (Hartm.) Fries. 
The wooded and open bogs of the ovoid islands have many bryophyte taxa in common, but the frequency of occurrence for some species varies greatly between features. This is particularly apparent for Sphagnum taxa. For instance, Sphagnum recurvum var. brevifolium is more widespread and common in wooded bogs, where it often grows in extensive loose carpets. Sphagnum magellanicum and S. fuscum, on the other hand, are not as well-represented in wooded bogs as they are in open bogs and thinly wooded ecotone strips. Dicranum ontariense, D. polysetum and Pleurozium schreberi are also particularly wellrepresented on hummocks in wooded areas.

Lichen communities are scattered on the floors of the marginal forested bogs, with Cladonia spp. most common. As in the open bogs, the best-developed lichen communities are usually associated with depressions. Fallen trees, stumps and newly exposed peat, however, also provide excellent substrates for lichen development. Most trees in the marginal forested bogs are at least partially covered with lichens, the most common being Parmelia caperata, P. flaventior, P. subaurifera, P. sulcata, P. ulophyllodes, Evernia mesomorpha, Hypogymnia physodes, Lecanora coilocarpa, Cetraria halei and Bryoria furcellata. In addition, Usnea hirta and U. subfloridana commonly hang from the trees, but they are neither so abundant nor so well-grown here as on trees on the teardrop islands. Although lichens are abundant in wooded bogs, the number of species is small.

Raised bogs, exemplified by the large, linear bog at the southern edge of area II, are dominated by Picea mariana. These crested bogs invariably display radiating wooded tongues that are also covered with this species. In general, trees of the raised bogs are taller and better grown than those of the marginal forests of the ovoid islands. The plants occurring in raised bogs are essentially the same as those found in the marginal forested bogs of the ovoid islands. However, Listera cordata was observed on raised bogs but not on the ovoid islands. The open drains that lie between the radiating tongues of wooded bog are dominated by Carex oligosperma and closely resemble the central open areas of the ovoid islands both floristically and in surface-water chemistry, and they are clearly ombrotrophic in nature.

Fire-formed bogs have a floristic composition somewhat different from undisturbed bogs in that characteristic species, such as Carex trisperma (common in wooded bogs) and C. oligosperma (common in open bogs), are uncommon or absent. In fire scars ericads are profuse and often densely grown and cyperaceous plants play only a minor role.

TABLE 5. - Vascular species confined to disturbed, partially dried-up fens and the environs of drainage ditches

Partially dried-up fens

Asclepias incarnata L., Bidens cernua L., B. connata Muhl. var. petiolata (Nutt.) Farwell, Cirsium arvense (L.) Scop., Gentiana rubricaulis Schwein., Gerardia paupercula (Gray) Britt. var. borealis (Pennell) Deam, Juncus alpinus Vill. var. rariflorus Hartm., Lycopus americanus Muhl., Lysimachia terrestris (L.) BSP, Parnassia glauca Raf., Scirpus atrocinctus Fern., Viola nephrophylla Greene.

\section{Drainage ditches (and adjacent margins)}

Alnus rugosa (Du Roi) Spreng., Apocynum cannabinum L., Betula papyrifera Marsh, B. X sandbergi Britt., Calamagrostis inexpansa Gray var. brevior (Vasey) Stebbins, Carex aquatilis Wahlenb. var. altior (Rydb.) Fern., C. aurea Nutt., C. bebbii (Bailey) Fern., C. lacustris Willd., C. lanuginosa Michx., C. projecta Mack., C. tenera Dew., C. vaginata Tausch, C. viridula Michx., Epilobium angustifolium L., Glyceria borealis (Nash) Batchelder, G. striata (Lam.) Hitchc., Hippuris vulgaris L., Juncus brevicaudatus (Engelm.) Fern., J. dudleyi Wieg., J. nodosus L., Mimulus ringens L., Nuphar variegatum Engelm., Pinus banksiana Lamb., Populus balsamifera L., Salix gracilis Anderss., S. interior Rowlee, S. lucida Muhl., S. planifolia Pursh, S. serissima (Bailey) Fern., Sium suave Walt., Spiraea alba Du Roi, Utricularia vulgaris L. 
Open poor fen. - Lying between the ombrotrophic and rich-fen areas are poor fens that have $p \mathrm{H}$ values lower than rich fens but usually higher than bogs. Ranging in size from narrow strips to meadow-like areas of several hectares, poor fens typically harbor a variety of bog species and one or more indicators of minerotrophy. Some species, such as Scirpus cespitosus var. callosus, Carex exilis, C. pauciflora, Eriophorum chamissonis and Habenaria lacera, occur in greater abundance in poor fen than in any other peatland habitat. In some places Scirpus cespitosus var. callosus and Carex exilis thrive so well that they extend for some distance into the fen, actually forming a floristically unique type of string. This string assemblage is particularly well-developed where the $\mathrm{N}$ branch of the western water track borders on the ovoid islands of area II.

One of the largest areas of weak minerotrophy in the peatland is situated within area II, lying between the large, linear raised bog and the ovoid islands to the N. It is an open, meadow-like area formed by the coalescence of numerous bog drains that fan out from the linear bog. Although the vegetation consists largely of Carex oligosperma growing in Sphagnum, the area differs floristically from the bog drains and the open bogs of the ovoid islands in that species such as Carex chordorrhiza, C. livida var. radicaulis, C. limosa, Scheuchzeria palustris and Rhynchospora alba are present. Significantly, Carex chordorrhiza is a reported indicator of minerotrophy in the Hudson Bay lowlands (Sjörs, 1963). The only lake (Hilman Lake) within the Red Lake Peatland is situated

TABle 6. - Bryophytes of the Red Lake Peatland

Mosses

Amblystegium serpens (Hedw.) BSG, Aulacomnium palustre (Hedw.) Schwaegr., Callicladium haldanianum (Grev.) Crum, Calliergon giganteum (Schimp.) Kindb., C. stramineum (Brid.) Kindb., Calliergonella cuspidata (Hedw.) Loeske, Campylium stellatum (Hedw.) C. Jens., Ceratodon purpureus (Hedw.) Brid., Climacium dendroides (Hedw.) Web. \& Mohr, Dicranum flagellare Hedw., D. montanum Hedw., D. ontariense Peters., D. polysetum Sw., D. undulatum Brid., Drepanocladus aduncus (Hedw.) Warnst., D. fluitans (Hedw.) Warnst., D. revolvens (Sw.) Warnst., Fissidens adiantoides Hedw., Helodium blandowii (Web. \& Mohr) Warnst., Hypnum lindbergii Mitt., H. pratense Koch ex Brid., Leptodictyum riparium (Hedw.) Warnst., Meesia triquetra (Richt.) Angstr., Plagiothecium denticulatum (Hedw.) BSG, Platygyrium repens (Brid.) BSG, Pleurozium schreberi (Brid.) Mitt., Pohlia nutans (Hedw.) Lindb., Pohlia sp., Polytrichum commune Hedw., P. juniperinum Hedw. var. affine (Funck) Brid., Pylasiella selwynii (Kindb.) Crum, Steere \& Anderson, Scorpidium scorpioides (Hedw.) Limpr., Sphagnum capillifolium (Weiss) Schrank, S. capillifolium (Weiss) Schrank var. tenellum (Schimp.) Crum, S. centrale C. Jens. ex Arnell \& C. Jens., S. cuspidatum Ehrh. ex Hoffm., S. fimbriatum Wils. ex J. Hook.*, S. fuscum (Schimp.) Klinggr., S. magellanicum Brid., S. majus (Russ.) C. Jens., S. obtusum Warnst.* , S. palustre L.* , S. papillosum Lindb., S. recurvum P.-Beauv. var. brevifolium (Lindb. ex Braithw.) Warnst., S. recurvum P.-Beauv. var. tenue Klinggr., $S$. russowii Warnst.* $S$. squarrosum Crome, S. subfulvum Sjors*, S. subsecundum Nees ex Sturm, $S$. subsecundum Nees ex Sturm var. contortum (Schultz) Hueb.*, S. subsecundum Nees ex Sturm var. platyphyllum (Lindb. ex Braithw.) Car., S. teres (Schimp.) Angstr. ex C. Hartm., S. warnstorfii Russ., Tetraphis pellucida Hedw., Thuidium recognitum (Hedw.) Lindb., Tomenthypnum nitens (Hedw.) Loeske.

Hepatics

Aneura pinguis (L.) Dum., Cephalozia connivens (Dicks.) Lindb., C. pleniceps (Aust.) Lindb., Cephaloziella elachista (Jack) Schiffn., Cladopodiella fluitans (Nees) Joerg., Fossombronia foveolata Lindb., Lophocolea heterophylla (Schrad.) Dum., Marchantia polymorpha L., Mylia anomala (Hook.) S. Gray, Plagiochila asplenioides (L.) Dum., Ptilidium pulcherrimum (Weber) Hampe, Scapania irrigua (Nees) Gott. et al.

*Sphagnum species marked with an asterisk were not recorded from the Red Lake Peatland during the 1978 study, but they were reported from there by Hofstetter (1969) and voucher specimens are deposited at MIN 
on the extreme western edge of this meadow-like area. The lake appears to be oligotrophic, and its origin is still unknown. No taxa were found in or around the lake that are not represented elsewhere in the peatland.

Wooded poor fen. - As mentioned previously, many wooded islands in areas II and III have poor-fen characteristics. Although the undervegetation on these islands strongly resembles that of wooded bog, they harbor clearly minerotrophic species such as Potentilla palustris and Carex brunnescens var. sphaerostachya (Sjörs, 1963). Carex chordorrhiza is also frequent on these islands but is largely confined to thinly wooded margins, where more light is available. It appears that the weak minerotrophic waters surrounding the islands restrict the number of species that can successfully invade; thus they are poorer in species than are the teardrop islands of area I, which are surrounded by nutrient-rich waters.

Wooded rich fen. - The teardrop islands, so numerous in the western water track (area I), are generally forested on the blunt, upstream ends and occupied by shrubs on the long downslope tails. Most islands display a pronounced hummock-hollow topography, with the hollows often containing standing water. The trees dominating the heads of the islands are Larix laricina and Picea mariana (with Thuja occidentalis occurring occasionally), but these are for the most part replaced by Betula pumila var. glandulifera on the tapered downstream tails.

The understory vascular flora on the islands is unusually rich and includes many species seldom found elsewhere in the peatland. Such species on hummocks are Aronia melanocarpa, Lonicera villosa var. solonis, L. oblongifolia, Rubus pubescens, Rumex orbiculatus, Osmunda cinnamomea, Polygonum sagittatum, Viola incognita and Carex disperma. In the hollows such species are Ranunculus gmelini var. hookeri, Sparganium minimum and Carex pseudo-cyperus. However, the islands harbor many species common elsewhere in the peatland, including, among others, Chamaedaphne calyculata, Ledum groenlandicum, Vaccinium oxycoccos, Carex canescens, C. paupercula, Bromus ciliatus, Agrostis scabra, Cirsium muticum, Cypripedium acaule and Drosera rotundifolia on hummocks, and Calla palustris, Menyanthes trifoliata and Typha latifolia in hollows.

As with the vascular plants, the moss flora is exceptionally rich on the teardrop islands and includes some species uncommon or absent elsewhere in the peatland, such as Climacium dendroides and Sphagnum squarrosum. The higher hummocks commonly bear

TABLE 7. - Lichens of the Red Lake Peatland

\begin{abstract}
Arthonia caesia (Körb.) Körb., Bacidia chlorococca (Graewe ex Stenh.) Lett., Bryoria furcellata (Fr.) Brodo \& Hawksw., B. trichodes (Michx.) Brodo \& Hawskw., Buellia arnoldii Serv. \& Nadv., $B$. punctata (Hoffm.) Mass., Calicium abietinum Pers., C. salicinum Pers., C. trabinellum (Ach.) Ach., Cetraria halei W. Culb. \& C. Culb., C. orbata (Nyl.) Fink, C. pinastri (Scop.) S. Gray, Cladonia bacillaris Nyl., C. botrytes (Hag.) Willd., C. cenotea (Ach.) Schaer., C. chlorophaea (Flk. ex Somm.) Spreng., C. coniocraea (Flk.) Spreng., C. crispata (Ach.) Flot., C. cristatella Tuck., C. deformis (L.) Hoffm., C. furcata (Huds.) Schrad., C. gracilis (L.) Willd., C. grayi Merr. ex Sandst., C. merochlorophaea Asah., C. mitis Sandst., C. multiformis Merr., C. pityrea (Flk.) Fr., C. rangiferina (L.) Wigg., C. rei Schaer., C. subulata (L.) Wigg., C. verticillata (Hoffm.) Schaer., Evernia mesomorpha Nyl., Hypogymnia physodes (L.) Nyl., Lecanactis chloroconia Tuck., Lecanora coilocarpa (Ach.) Nyl., L. meridionalis Magn., L. pallida (Schreb.) Rabenh., L. strobilina (Spreng.) Kieff., L. symmictera Nyl., L. thysanophora Harris, Lecidea elaeochroma (Ach.) Ach., L. flexuosa (Fr.) Nyl., L. uliginosa (Schrad.) Ach., Lepraria finkii (B. de Lesd. in Hue) Harris, Micarea melanobola (Nyl.) Harris, Mycocalicium subtile (Pers.) Szat., Parmelia bolliana Mull. Arg., P. caperata (L.) Ach., P. exasperatula Nyl., P. flaventior Stirt., P. olivacea (L.) Ach., P. rudecta Ach., P. subaurifera Nyl., $P$. subrudecta Nyl., $P$. sulcata Tayl., P. ulophyllodes (Vain.) Sav., Parmeliopsis aleurites (Ach.) Nyl., P. capitata Harris, Physcia millegrana Degel., P. stellaris (L.) Nyl., Pseudevernia consocians (Vain.) Hale \& Culb., Ramalina dilacerata (Hoffm.) Hoffm., R. fastigiata (Pers.) Ach., Rinodina milliaria Tuck., Sphinctrina turbinata (Pers. ex Fr.) De Not., Usnea cavernosa Tuck., U. fulvoreagens (Räs.) Räs., U. hirta (L.) Wigg., U. subfloridana Stirt.
\end{abstract}


a moss cover of Sphagnum warnstorfii, S. centrale, Polytrichum juniperinum var. affine, Pleurozium schreberi and Aulacomnium palustre. The lower hummocks are mostly covered with Sphagnum teres, $S$. centrale and $S$. recurvum var. brevifolium. Although some hummocks on the islands display a quasi-vertical zonation of mosses, most often the species of Sphagnum grow in pure colonies and not in the well-defined mosaic of species so commonly found in the open bogs. The moss Pylasiella selwynii is often present at or near the bases of trees, and Tetraphis pellucida and Callicladium haldanianum frequently occur on rotting logs. Mosses commonly associated with hollows are Campylium stellatum, Drepanocladus aduncus, and Calliergon giganteum. Other mosses consistently present on the islands include, among others, Calliergon stramineum, Hypnum lindbergii, Pohlia nutans and, somewhat less commonly, Plagiothecium denticulatum, Leptodictyum riparium and Thuidium recognitum.

The hepatics are also floristically richer on the teardrop islands than elsewhere in the peatland. When hummocks have been disturbed by fallen trees or by animals (e.g., the moose, Alces alces, is known to visit the islands), their sides often become colonized by Mylia anomala, Cephalozia pleniceps and Cladopodiella fluitans. Other hepatics not infrequently found on the islands are Scapania irrigua, Ptilidium pulcherrimum, Fossombronia foveolata, Lophocolea heterophylla and Plagiochila asplenioides. In addition, Aneura pinguis is often present along the edges of hollows.

The wet and humid teardrop islands provide a diversity of habitats for lichens, especially on trees, logs, old stumps, bases and lower branches of bushes, and areas with thin or slow-growing mosses. Species consistently present on tree bark are Parmelia caperata, P. flaventior, Evernia mesomorpha, Hypogymnia physodes, Lecanora coilocarpa, Bryoria furcellata and Cetraria halei. In addition, Bacidia chlorococca is often present on dead twigs at the ends of small branches, and Cetraria pinastri and Parmeliopsis capitata are commonly associated with tree bases. Usnea hirta and U. subfloridana commonly hang from the trees, sometimes in large festoons. The hummocky surfaces of the islands also harbor several lichen species, notably Cladonia mitis and $C$. rangiferina.

Strings. - The strings of the patterned fens are dominated by Betula pumila var. glandulifera, Chamaedaphne calyculata, Andromeda glaucophylla and Vaccinium oxycoccos. Other taxa commonly occurring on string hummocks are Salix pedicellaris var. hypoglauca, Sarracenia purpurea, Thelypteris palustris var. pubescens, Carex tenuiflora, C. cephalantha, Arethusa bulbosa and Drosera rotundifolia. Stunted trees of Larix laricina are also generally present on the better developed strings.

The moss flora of the strings is much richer than that of the surrounding flarks. Although string hummocks vary greatly in height, nearly all display a vertical zonation of species. The taller hummocks have, from top to bottom, Sphagnum fuscum, $S$. capillifolium var. tenellum, S. magellanicum, $S$. recurvum var. brevifolium and $S$. majus. In many instances, however, Polytrichum juniperinum var. affine occurs on the tops of the higher hummocks instead of Sphagnum fuscum. Also, quite often S. capillifolium var. tenellum or $S$. magellanicum dominate the tops of the lower hummocks. Other mosses commonly associated with strings are Aulacomnium palustre and Sphagnum recurvum var. tenue. Less commonly occurring species include, among others, Tomenthypnum nitens, Calliergonella cuspidata and Meesia triquetra.

Lichens are not abundant on string hummocks but sometimes small communities do occur, with most containing one or more species of Cladonia. The trees on the strings are usually at least partially covered with lichens, Parmelia spp. being most common.

Flarks. - Whereas some species, such as Carex chordorrhiza, C. limosa and Pogonia ophioglossoides, grow both on string hummocks and in flarks, most vascular plants that frequent flarks do not grow on the best-developed strings. Species dominating the fiarks are Carex lasiocarpa var. americana, C. livida var. radicaulis and Menyanthes trifoliata. Many other species are consistently present, among them Carex leptalea, Rhynchospora alba, Utricularia intermedia, U. minor, Drosera intermedia, Triglochin maritima and Scheuchzeria palustris. Also in the flarks, though occurring less commonly, are Utricularia 
cornuta, Cladium mariscoides and Drosera anglica. In some fens Rhynchospora fusca is a regular constituent, often forming dense clones (this is especially evident in area II). Drosera linearis is occasionally found in flarks in the western water track, but it is not known from the central and eastern portions of the peatland.

In general, the bryophyte flora of flarks is impoverished. The common mosses are Scorpidium scorpioides, Campylium stellatum, Drepanocladus revolvens and Sphagnum subsecundum. Where low moss cushions have developed, Sphagnum papillosum, S. recurvum var. tenue, S. magellanicum and Aulacomnium palustre are often present.

As mentioned earlier, unvegetated areas of open water sometimes occur in the fens. These fen-pools generally have a rounded outline, but they vary greatly in size. Although flark species dominate the borders of these pools, the edges sometimes harbor plants that are otherwise uncommon or absent from the flarks themselves, notably Xyris montana, Juncus stygius var. americana, J. pelocarpus, J. canadensis and Scirpus validus. In the water tracks of area IV the fen-pools attain their best development, often reaching several meters in diameter.

Disturbed areas. - Ditching and roadbuilding in the peatland have had, and continue to have, distinct effects upon the vegetation. Drainage ditches cut through large portions of the peatland and are particularly evident in area II and the western portion of area III. The margins of the ditches often harbor taxa unknown from undisturbed portions of the peatland, such as Alnus rugosa, Spiraea alba, Mimulus ringens, Carex viridula and several species of Salix. Also, drying out downstream and occasional flooding upstream have marked effects upon the fen water tracks. Particularly noticeable is the extensive growth of Betula pumila var. glandulifera on the drier, downslope sides of the ditches. The N-S highway that transects area II has caused such severe drying W of the road that the ribbed pattern is obliterated for more than $0.4 \mathrm{~km}$ inland. Species such as Asclepias incarnata and Cirsium arvense, which now grow in abundance in these partially dried-up fens and along the edges of drainage ditches, are unknown from the undisturbed portions of the peatland (Table 5).

\section{Carex of the Red Lake Peatland}

GENERAL OCGURRENCE

Although the Red Lake Peatland has a depauperate vascular flora, the cyperaceous plants are more strongly represented in the mire, both in number of taxa and number of individuals, than in surrounding vegetation types (e.g., mixed conifer-hardwood forest). This is particularly true of Carex, the species of which account for $15 \%$ of the peatland vascular flora. Many carices are greatly affected by the chemical nature of the water in which they grow, and often, only a slight variation in water chemistry will determine whether a particular species will be present or absent from a particular site. Indeed, no other genus present in the peatland has as many species as Carex and, with the possible exception of Sphagnum, no other genus covers such a diversity of habitats and plays such an important ecological role.

Twenty-nine species of Carex are known from the Red Lake mire (Table 8), 20 of which occur in the bogs and fens of the peatland proper. The remaining nine taxa are known only from markedly disturbed portions of the peatland, such as the partially dried-up fens that lie adjacent to the N-S highway and along the margins of drainage ditches.

SPECIES OCGURRING ON OMBROTROPHIG SITES

Four species of Carex, C. oligosperma, C. trisperma, C. pauciflora and C. paupercula, are widespread and often occur in abundance on sites having $p \mathrm{H}$ values less than 4.5 ; and with the exception of $C$. paupercula, they rarely occur on sites with a $p \mathrm{H}$ greater than 5 (Fig. 2).

Almost invariably, Carex oligosperma is the dominant vascular plant in open bogs of the ovoid-shaped islands, in open ombrotrophic seepage areas that drain raised bogs, 
and in open poor-fen areas where bog drains coalesce. The species is uncommon or absent from forested bogs, thinly wooded ecotone strips, and open bogs that have only recently been deforested by fire or clear-cutting.

Carex oligosperma displays a narrow $p \mathrm{H}$ tolerance in the mire (Fig. 2), and it is not known from poor-fen sites having calcium values greater than $3.2 \mathrm{mg} / \mathrm{liter}$. The plant is strongly rhizomatous and is best distinguished by its involute leaves and fewflowered, pistillate spikes that bear inflated, glabrous perigynia. Carex oligosperma is clearly heliophilous and appears unable to tolerate even small amounts of shade.

Several higher plants often grow in association with Carex oligosperma in open bogs, the most noteworthy being Eriophorum spissum, Ledum groenlandicum, Chamaedaphne calyculata, Vaccinium oxycoccos, Andromeda glaucophylla, Kalmia polifolia, Sarracenia purpurea and Drosera rotundifolia. Unlike Carex oligosperma, however, all of these associates are also known from forested bogs, and each of these species, with the exception of Eriophorum spissum, is known from sites having $p \mathrm{H}$ values greater than 4.5 (Fig. 3) and calcium values in excess of $3.2 \mathrm{mg} / \mathrm{liter}$.

Wooded bogs harbor few Carex species, but $C$. trisperma is a regular constituent in
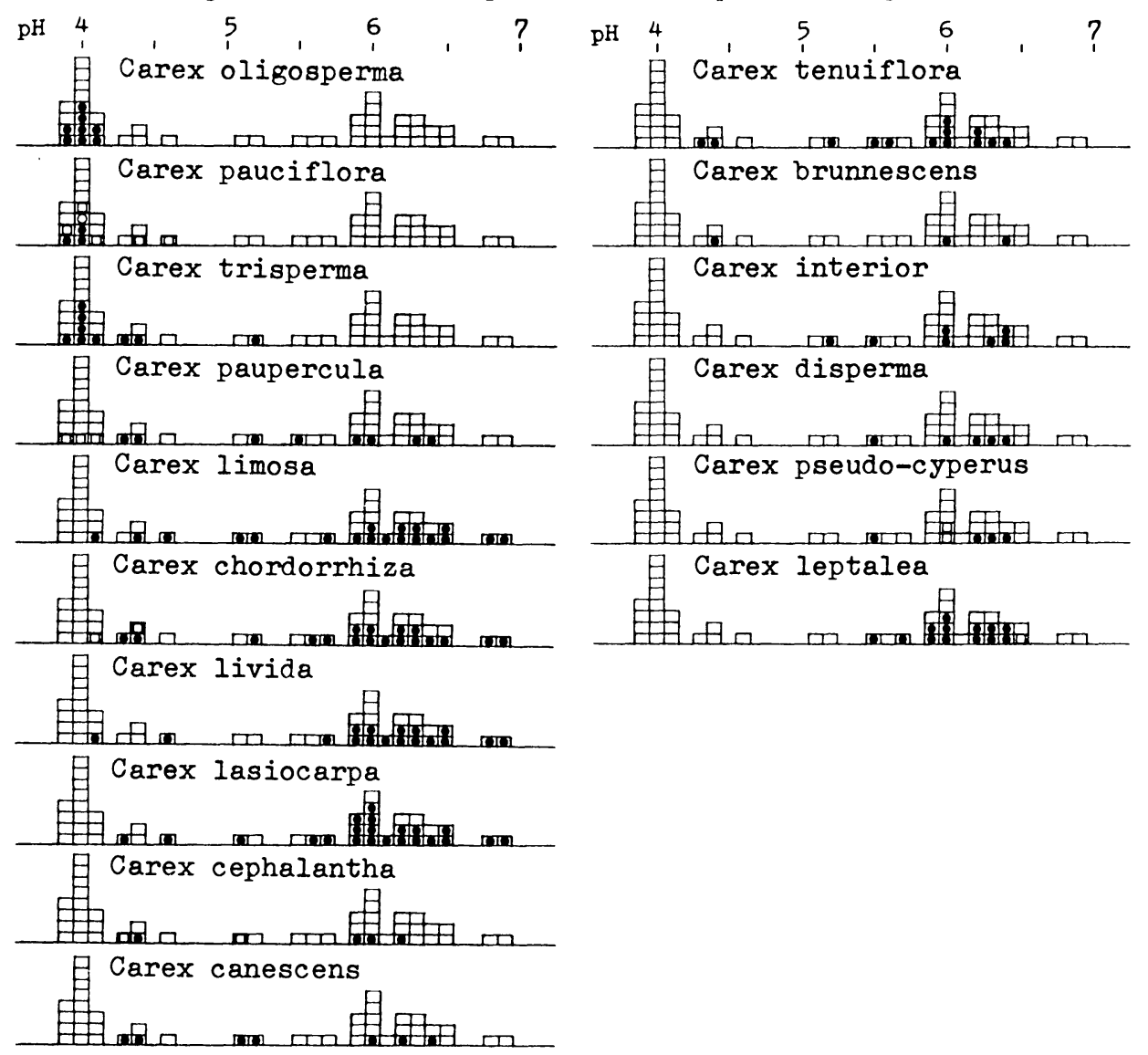

Fig. 2. - The $p \mathrm{H}$ distributions of 16 species of Carex from the Red Lake Peatland. Square blocks represent the number of sites recorded at a given $p \mathrm{H}$ (to the nearest $0.1 p \mathrm{H}$ unit). Closed circle within block = species occurring within study plot; open circle = species occurring just outside study plot (within $10 \mathrm{ft}$ of plot border); open square = species occurring near study plot but more than $10 \mathrm{ft}$ from the plot border 


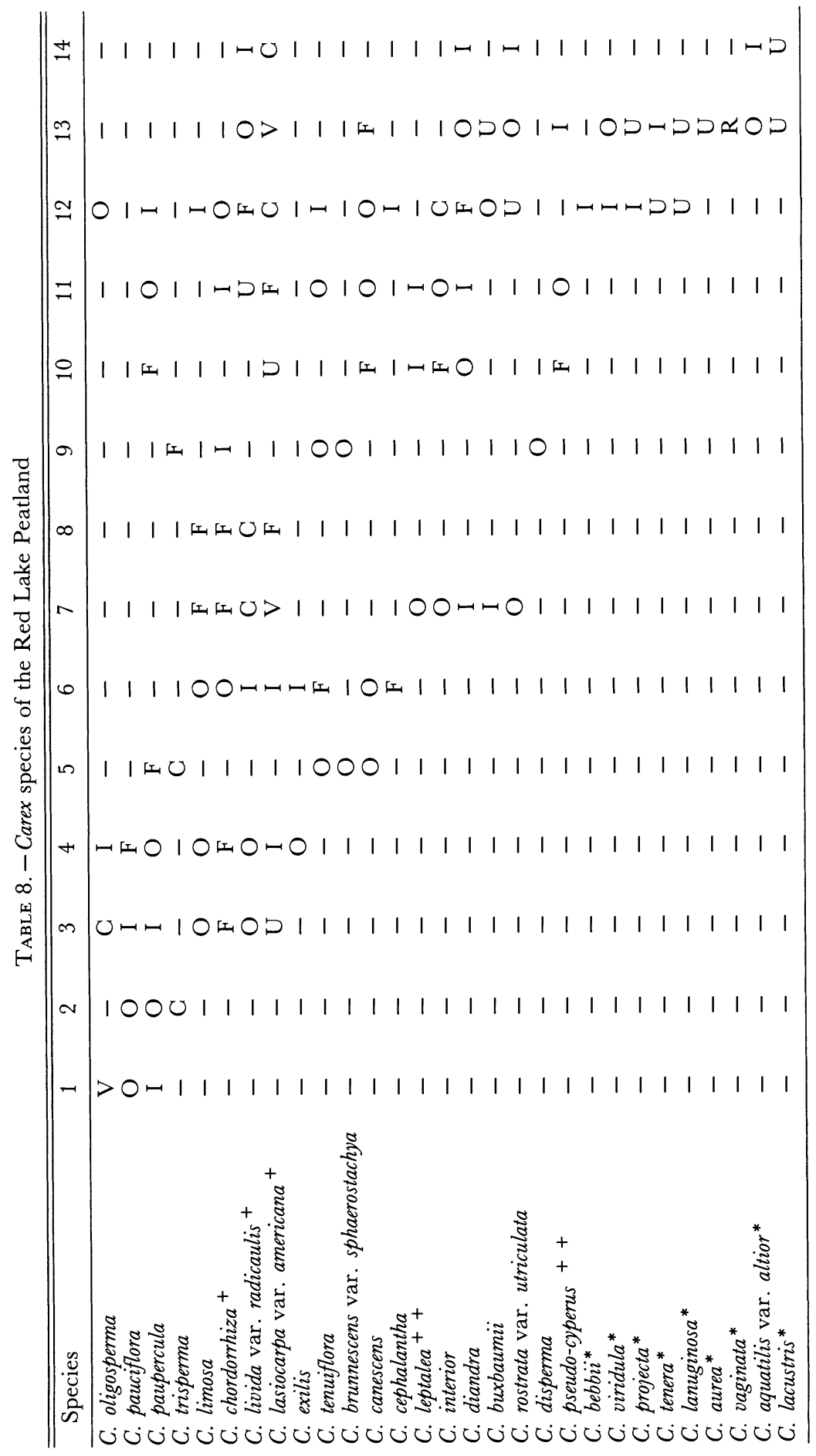




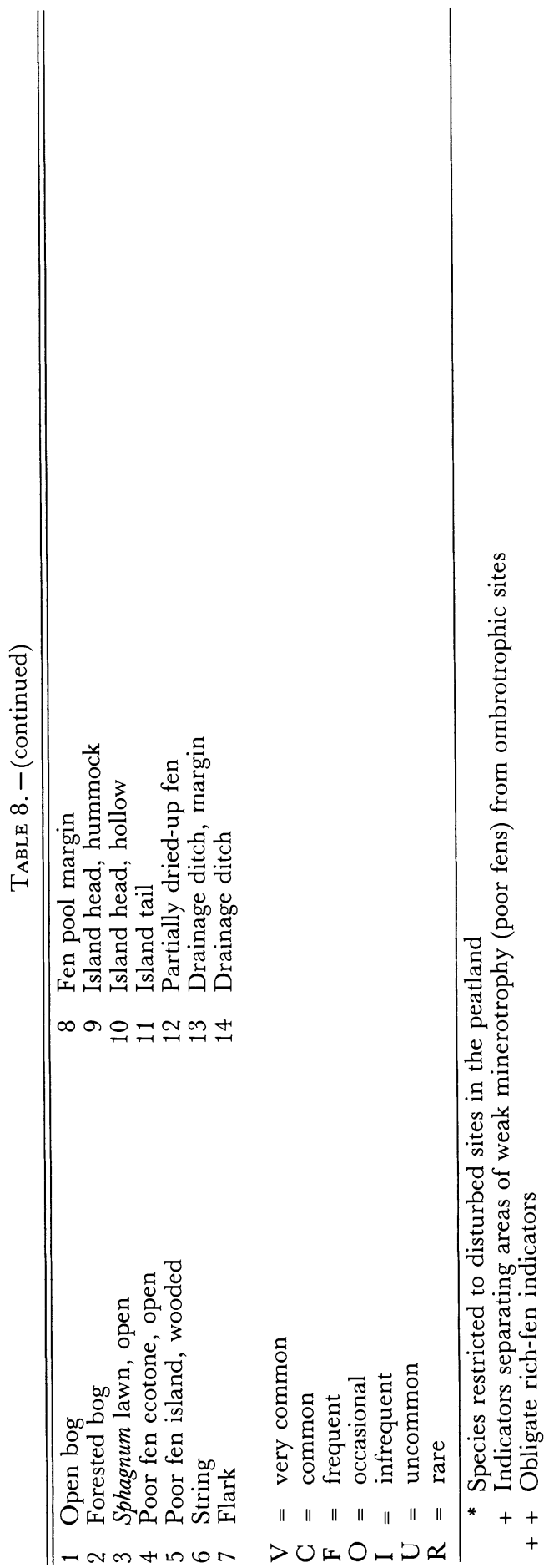


this habitat and is sometimes the dominant vascular plant in the field layer. It often grows together with Sphagnum recurvum var. brevifolium, the former growing in the low, loose carpets of the latter. Carex trisperma is also a common member of the field layer on poor-fen wooded islands and is occasional on the wooded heads of the teardrop islands. The species is uncommon or absent in open bogs and fire scars, and it grows poorly in thinly wooded ecotone strips. Carex trisperma is clearly sciaphilous, growing abundantly at low light intensities and rarely in full sunlight.

The few-flowered, widely separated spikes of Carex trisperma superficially resemble those of $C$. disperma, but the former has its lowest spike subtended by an elongated bract. Furthermore, whereas the spikes (two or three) of $C$. trisperma are gynaecandrous, the spikes (2-7) of $C$. disperma are androgynous.

With the exception of hummocks on the teardrop islands (for which no $p \mathrm{H}$ values are available), Carex trisperma grows in forested sites whose surface-waters have a $p \mathrm{H}$ less than 5.3 (Fig. 2) and calcium values below $5.3 \mathrm{mg} / \mathrm{liter}$. On the teardrop islands, C. trisperma is present only on the highest hummocks, its roots and rhizomes embedded in Sphagnum and not in direct contact with minerotrophic surface waters. Although no moist peat samples were taken from the tops of hummocks harboring this species, it is

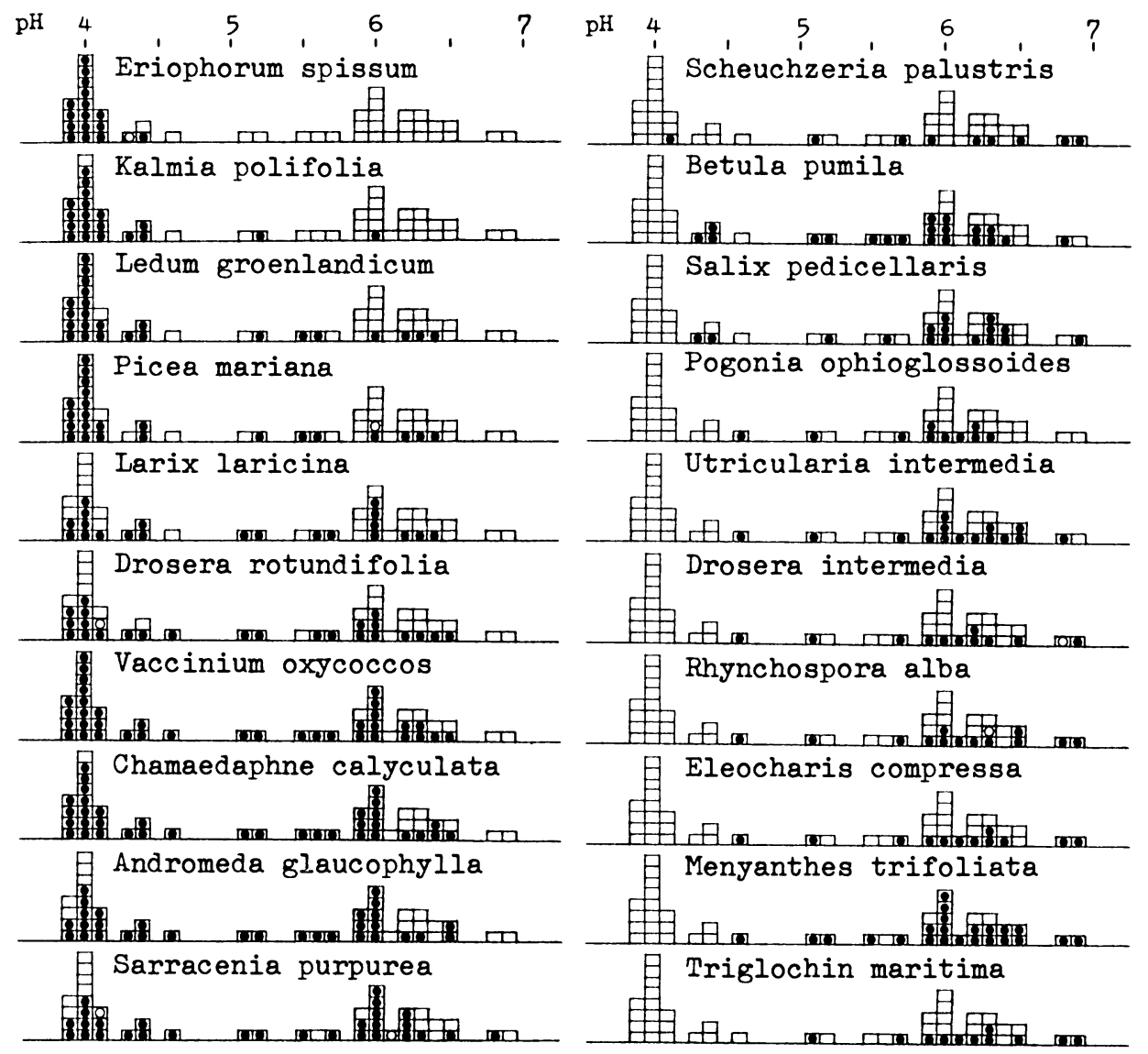

Fig. 3. - The $p \mathrm{H}$ distributions of 20 species of vascular plants from the Red Lake Peatland. Square blocks represent the number of sites recorded at a given $p \mathrm{H}$ (to the nearest $0.1 p \mathrm{H}$ unit). Closed circle within block $=$ species occurring within study plot; open circle $=$ species occurring just outside study plot (within $10 \mathrm{ft}$ of plot border) 
suspected that the $p \mathrm{H}$ near the tops of the higher hummocks is lower than that of the surface waters and is probably weakly acid. Indeed, no obligate rich-fen species were found on the tops of these hummocks. Instead, species such as Vaccinium vitis-idaea var. minus, Smilacina trifolia, Gaultheria hispidula, Monotropa uniflora and Cypripedium acaule were found, all of which are best known from ombrotrophic and poor-fen sites. In this regard, it is significant that workers in northern Michigan (Vitt et al., 1975b) found a $p \mathrm{H}$ gradient existing between the bottoms (more alkaline) and tops (more acid) of large Sphagnum hummocks, the difference being as much as 1.0 to $1.5 p \mathrm{H}$ units.

In the Red Lake area, Carex pauciflora is occasional in ombrotrophic sites, growing primarily on the edges of wet hollows in open bogs and along the outer margins of forested bogs. Although tolerant of acid sites, the species occurs most often on sites that

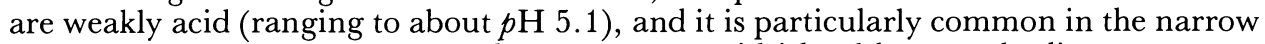
strips of open poor-fen ecotone that separate ovoid island bogs and adjacent narrow water tracks. The species is not known from sites having calcium values greater than 5 $\mathrm{mg} / \mathrm{liter}$.

Carex pauciflora is easily recognized by the long-pointed, slender perigynia that are strongly reflexed at maturity and which no doubt are readily dispersed by animals. The species grows best where the water table is at or close to the peat surface, but it is invariably absent from sites that have a mud substrate. Although sometimes occurring on low hummocks, C. pauciflora rarely grows on the tops of high hummocks or in other dry sites. Because the plant also grows poorly in deeply shaded situations, it rarely frequents the centers of forested bogs or the interiors of the poor-fen wooded islands.

In the peatland, Carex paupercula grows along the edges of wet hollows in open bogs, on the outer margins of forested bogs, and in the narrow strips of poor-fen ecotone that separate bogs from rich fens. However, it is on the teardrop and wooded poor-fen islands where the plant is most widespread and common. On these islands, C. paupercula grows in wet spaces between hummocks, the characteristic yellow, felt-covered roots coming in direct contact with minerotrophic surface waters. The species occurs on sites having calcium values up to $11.6 \mathrm{mg} / \mathrm{liter}$; the $p \mathrm{H}$ range is given in Figure 2.

Carex paupercula greatly resembles and is closely related to another peatland sedge, C. limosa, but in the mire the former does not grow on such nutrient-rich sites as the latter (see Fig. 2), and the habitats for the two taxa are for the most part different. In some open poor-fen areas, however, the two species grow together.

\section{SPECIES OGCURRING ON MINEROTROPHIC SITES}

Excluding the four taxa discussed above, 25 species of Carex are known from minerotrophic sites in the peatland. Of these, three species are essentially restricted to wooded islands and nine are known only from disturbed sites. The remaining 13 species are best known from open fens.

Carex lasiocarpa var. americana is by far the most widespread and common vascular plant in open rich-fen sites, and it often forms large, commonly sterile stands in flarks. This strongly rhizomatous sedge also grows on low, incipient strings and along the margins of fen pools and, less commonly, in open poor-fen areas. The plant grows over a wide range of $p \mathrm{H}$ (Fig. 2) and calcium (4.0 to $19.6 \mathrm{mg} / \mathrm{liter}$ ) values. Carex lasiocarpa var. americana is clearly heliophilous, and its wire-like, involute leaves and densely pubescent perigynia are characteristic.

In extremely wet, deep flarks, plants of Carex lasiocarpa var. americana grow unusually tall, presumably from lack of competition and changes brought about by submergence. The uptake of nutrients must be near optimal here and may relate to the large number of plants in flower and fruit. Only a limited number of vascular taxa frequent these sites, such as Potamogeton gramineus, Utricularia intermedia, U. minor, Menyanthes trifoliata, and less commonly Phragmites communis var. berlandieri and Cladium mariscoides.

In shallower and less wet flarks the number of vascular taxa is much greater, and 
here plants of Carex lasiocarpa var. americana are shorter and commonly sterile, presumably owing to the severe competition and concomitant reduction in nutrient uptake. Among the more common vascular taxa present here are Carex livida var. radicaulis, C. limosa, Eleocharis compressa, Drosera intermedia, Menyanthes trifoliata, Pogonia ophioglossoides, Rhynchospora alba, Scheuchzeria palustris, Triglochin maritima, and Utricularia intermedia (Fig. 3).

As just indicated, Carex livida var. radicaulis is a common constituent of open fen, where it grows over a wide range of $p \mathrm{H}$ (Fig. 2) and calcium (3.2 to $19.6 \mathrm{mg} / \mathrm{liter}$ ) values. It is a strongly rhizomatous sedge that is clearly heliophilous, and its pronounced white-glaucous leaves stand in marked contrast to the otherwise deep-green vegetation. Carex livida var. radicaulis is frequent to common in fen flarks and on low, newly formed hummocks, and it is generally present in great abundance along the margins of fen-pools. In contrast, it is uncommon in extremely wet, deep flarks.

Besides occurring in rich fen, Carex livida var. radicaulis also occurs in poor-fen sites, and although some of the latter display a considerable physiognomic resemblance to ombrotrophic bog, the presence of this species readily distinguishes them as poor fen. Indeed, in the mire this taxon frequently serves as a poor-fen indicator that separates weakly minerotrophic sites from true ombrotrophic sites.

In the peatland, both Carex limosa and $C$. chordorrhiza are regular constituents in open poor- and rich-fen sites, but they rarely occur in such abundance in open rich fen as the two sedges discussed above. Carex chordorrhiza is particularly common in open poor fen, where it frequently serves as an indicator of minerotrophy in seepages and other wet parts of the ecotones between ombrotrophic and minerotrophic sites. Although C. limosa is reported from ombrotrophic bogs elsewhere (Sjörs, 1961, 1963), it is not known from bogs in the Red Lake area:

Carex limosa grows in sites having a wide range of $p \mathrm{H}$ (Fig. 2) and calcium (2.7 to $19.6 \mathrm{mg} / \mathrm{liter}$ ) values. In open fen the species is widespread and common in flarks, but it also occurs on string hummocks, even those elevated several centimeters above the peat surface. The culms and shoots of the plant arise singly from slender, long-creeping rootstocks that are usually situated at or near the peat surface. Its roots, like those of most peatland Carex species, are thick and mostly without secondary roots, much unlike carices of dry and sandy sites, which typically have wiry and many-branched roots. Furthermore, the roots of $C$. limosa, like those of the closely related $C$. paupercula, are conspicuously covered with numerous yellowish-tinged root hairs. Carex limosa is heliophilous, but it does occur occasionally in partially shaded sites.

Carex chordorrhiza grows over a wide range of $p \mathrm{H}$ (Fig. 2) and calcium (2.7 to 19.6 $\mathrm{mg} / \mathrm{liter}$ ) values and, as mentioned above, it is a frequent indicator of minerotrophy in the mire. The plant seems to require at least moderate light for best growth, and it seldom grows under a closed conifer canopy. Carex chordorrhiza has a most unusual and well-marked habit of growth, where old prostrate culms of the previous year give rise to new plants from the nodes. The cord-like stems can reach great lengths and sometimes creep for many decimeters over and under the peat surface, particularly in lawn areas.

Carex leptalea is an obligate rich-fen indicator in the Red Lake mire, and it has been reported as such elsewhere (Sjörs, 1963). In the Red Lake area, the species is known only from sites having surrounding surface waters with a $p \mathrm{H}$ greater than 5.4 (Fig. 2); for 13 sites the average $p \mathrm{H}$ was 6.1 and the average calcium concentration 10.2 $\mathrm{mg} /$ liter. Although $C$. leptalea occurs in open fen (in flarks and on strings), it grows most abundantly in moss-laden, shaded habitats. Because the plant produces dense mats only in deeply shaded places, it appears that reduced light greatly favors asexual propagation in the species. Carex leptalea is easily recognized by its solitary, androgynous spike that bears small, erect, beakless perigynia.

Carex interior grows in flarks throughout the peatland but is seldom found in great abundance. It also occurs on the teardrop islands, where it grows along the margins of water-filled hollows in both the wooded heads and shrub-laden tails. According to 
Damman (1964), the species grows on richer sites than the closely related C. cephalantha, and this seems to hold in the Red Lake area (Fig. 2). Carex interior grows in cespitose clumps and is distinguished by the three (2-7) "star-like" clusters of spikes, the terminal one of which is often long-clavate at the base. Although occurring in the peatland proper, the species is best known from disturbed sites, particularly the partially driedup fens of area III; here its cespitose clumps are well-developed and often present in abundance.

Three other Carex taxa, C. diandra, C. buxbaumii and C. rostrata var. utriculata, grow in flarks, but none is of more than occasional occurrence. Neither $C$. buxbaumii nor $C$. rostrata var. utriculata is well-represented on any landscape feature in the peatland, but the latter is frequent in lagg areas and along the margins of creeks bordering the mire.

In the partially dried-up fens W of the major N-S highway (area III), Carex diandra is widespread and common. Here the densely cespitose clumps or "tussocks" of this species are particularly well-developed and abundant, and it appears that the great mass of decayed material added to the surface each year by this taxon creates a substrate even more favorable to its continued growth and expansion. Carex diandra also occurs frequently on the teardrop islands, where it grows along the edges of wet hollows and in wet spaces between hummocks.

Although scattered in the peatland, Carex exilis is sometimes abundant in the narrow strips of ecotone that separate ovoid island bogs from adjacent narrow water tracks. The largest known population is where the $\mathrm{N}$ branch of the western water track (area I) borders on the ovoid islands of area II. The species thrives so well here that it extends some distance into the fen on string hummocks.

The aforementioned strings are dominated by Carex exilis and Scirpus cespitosus var. callosus and differ floristically from strings in other parts of the peatland, which in most cases are dominated by Betula pumila var. glandulifera and various shrubby ericads. The sedge-dominated strings are poor in species, presumably owing to the densely cespitose habit of both C. exilis (which is deep-rooting) and Scirpus cespitosus var. callosus (which is shallow-rooting). Indeed, the conditions of competition in such dense colonies must be severe; yet, because the mode of root and rhizome growth and the vertical stratification of the two species are different, they are not close competitors themselves.

Carex exilis occurs most often in sites that are weakly acid (average $p \mathrm{H}$ ca. 4.5 and calcium values averaging about $4 \mathrm{mg} / \mathrm{liter}$ ), but can tolerate sites that are much less acid (up to $p \mathrm{H} 6.2$ and calcium values up to $12.6 \mathrm{mg} / \mathrm{liter}$ ). The species is strongly heliophilous and seldom grows in even partial shade. It is distinguished by its usually solitary, gynaecandrous spike (plants may occasionally be dioecious), wiry, involute leaves, and densely cespitose habit.

Whereas Carex exilis occurs only rarely on strings, $C$. cephalantha, $C$. tenuiflora and $C$. canescens are rather common on this landscape feature and sometimes grow in abundance. Strings harboring $C$. cephalantha are characterized by surrounding surface waters that range from rather acid to somewhat below neutral (calcium values range from 4.3 to $12.2 \mathrm{mg} /$ liter; the $p \mathrm{H}$ range is given in Fig. 2). Carex cephalantha grows in large colonies and is distinguished by its usually 5-9 "star-like" clusters of spikes and densely cespitose habit. This heliophilous sedge is mostly restricted to strings in the peatland proper, but it also occurs in the partially dried-up fens in area III.

In the mire, Carex tenuiflora occurs on strings and also frequents wooded poor-fen and teardrop islands. It often forms large colonies on string hummocks, but they are rather loosely compacted instead of densely cespitose like those of $C$. cephalantha. On the teardrop islands $C$. tenuiflora is occasional to frequent, growing primarily on low hummocks in both the wooded heads and shrubby tails; it is also of occasional occurrence on low hummocks in the wooded poor-fen islands. The species appears to grow well in both open and shaded sites.

Carex tenuiflora is present in sites having calcium values ranging from 3.2 to 18.4 $\mathrm{mg} /$ liter; the $p \mathrm{H}$ range is given in Figure 2. The report by Sjörs (1963) that $C$. tenuiflora 
is an obligate rich-fen indicator in the Hudson Bay lowlands does not hold for the Red Lake area. Indeed, in the Red Lake Peatland many of the strings and wooded islands (areas II and III) that harbor this species clearly display poor-fen characteristics.

Whereas Carex cephalantha and C. tenuiflora occur primarily on the tops of strings, $C$. canescens is mostly associated with the lower, outer margins of string hummocks, where it grows in small colonies. The last-named species is also common in wet hollows on the teardrop islands (heads and tails) and the wooded poor-fen islands, and it is a frequent constituent on the margins of drainage ditches and in wet depressions in disturbed fens. Carex canescens has a cespitose habit and is best distinguished by its glaucous foliage and 4-8 whitish spikes, each bearing 10-30 perigynia; the plant grows in both open and shaded sites.

Three Carex taxa, C. brunnescens var. sphaerostachya, C. disperma and C. pseudo-cyperus, are present on minerotrophic wooded islands but essentially absent from other peatland features. The first two grow on hummocks in the wooded heads of the teardrop islands, whereas the latter is present in both the wooded heads and shrubby tails, growing in wet spaces between hummocks and along the edges of water-filled hollows. Of the three taxa, only $C$. brunnescens var. sphaerostachya frequents the wooded poor-fen islands. This species grows primarily in shaded places, and it occurs on sites having calcium values that range from 4.8 to $11.6 \mathrm{mg} / \mathrm{liter}$; the $p \mathrm{H}$ range is given in Figure 2 .

Carex disperma is confined to the wooded heads of the teardrop islands, where it grows on the tops of hummocks and, less commonly, along their lower, outer margins. The $p \mathrm{H}$ values given for this species in Figure 2 are limited to sites near the bottoms of hummocks; but because this species also occurs on the tops of hummocks, where conditions are presumably more acid, it is more than likely that the plant extends over a somewhat wider range of $p \mathrm{H}$ than indicated in the above-mentioned figure. Carex disperma is more or less restricted to deeply shaded sites on the islands and, as suggested by some workers (Dansereau and Segadas-Vianna, 1952), reduced light seems to be a requirement for its best growth.

Although Carex pseudo-cyperus grows locally along drainage ditches in rich-fen areas, it is best known from wet hollows on the teardrop islands. The species occurs only in sites having $p \mathrm{H}$ values of 5.5 or greater (Fig. 2) and calcium values exceeding 18.3 $\mathrm{mg} / \mathrm{liter}$; it is clearly an obligate rich-fen minerotroph in the mire.

Several species of Carex grow in disturbed sites in the peatland, nine of which are unknown from undisturbed portions of the mire (Table 8). It is assumed that the latter have only recently entered the peatland, most likely following the construction of the major highway and drainage ditches. Of the nine species, only $C$. aquatilis var. altior extends into the peatland interior, where it grows locally in drainage ditches and on adjacent margins. Although these carices are associated with disturbed sites, they presently form an integral part of the peatland flora and no doubt will continue to spread with future disturbance in the area.

The Carex species restricted to disturbed sites seldom occur in great abundance in the peatland, but some of them, such as $C$. aquatilis var. altior and $C$. lacustris, are widespread and common along the margins of creeks bordering the mire and in lagg areas. For instance, along Troy Creek, which drains $\mathrm{N}$ from the peatland into the Rapid River, C. aquatilis var. altior grows codominantly with Calamagrostis canadensis, often to the near exclusion of other vascular taxa. Carex lacustris also is common in laggs on the northern boundary of the peatland, and it is the dominant species in the drainage ditches bordering the N-S highway. Other carices common in highway verges are $C$. viridula, $C$. lanuginosa and $C$. aurea.

Two additional Carex species, C. comosa and C. stricta, have been reported from the Red Lake Peatland (Hofstetter, 1969), but they were not found during the 1978 study. Because no voucher specimens could be located for examination, it seems best to await further verification before they are included in the peatland flora. And finally some 20 species of Carex are known from marginal communities that neither occur in the 
peatland proper nor on disturbed sites in the mire (Wheeler, unpubl. data).

\section{Comparisons with Carex from Peatlands Elsewhere GENERAL REMARKS}

It is clear from the literature as well as from our study, that the genus Carex plays a most conspicuous and important role in peatland ecology. When comparing floristic and ecological data from various peatlands, however, one finds that the species of Carex involved are not always the same, and in yet other instances a given species may grow under slightly differing conditions in different areas. Therefore, a comparison may be interesting between the Carex of the present area of investigation and that of peatlands elsewhere.

\section{SPECIES OCGURRING ON OMBROTROPHIC SITES}

Of the four Carex species occurring in ombrotrophic sites in the Red Lake Peatland (Table 2), all are reported from bogs in the Hudson Bay lowlands (Sjörs, 1963), and one of them, C. pauciflora, occurs in bogs in northern Fennoscandia (Sjörs, 1948, 1963; Eurola and Kaakinen, 1978). Although C. paupercula is present in bogs in the Hudson Bay (Sjörs, 1963) and Red Lake areas, it is essentially a species of minerotrophic sites in northern Fennoscandia (Sjörs, 1963). On the other hand, C. limosa is known from bogs in both the Hudson Bay lowlands (Sjörs, 1961, 1963) and northern Fennoscandia (Malmer, 1962; Sjörs, 1963; Eurola and Kaakinen, 1978) but is restricted to minerotrophic sites in the Red Lake Peatland. Carex rariflora is reported from bogs in northern Fennoscandia (Eurola and Kaakinen, 1978), but it does not occur in the Red Lake Peatland (or in Minnesota). In the Hudson Bay lowlands, C. rariflora is reported from the Kinoje Lakes area (Riley and McKay, 1980), but we do not know if it occurs on ombrotrophic sites there.

Carex oligosperma is a plant of northern North America that does not have a closely related counterpart in European peatlands. In Canada, the species extends as far westward as Great Bear Lake in the Northwest Territories (Scoggan, 1978); in the United States, the Red Lake Peatland harbors the westernmost stations.

In both the Hudson Bay (Sjörs, 1963) and Red Lake areas, Carex oligosperma plays an important ecological role in open, meadow-like, poor-fen areas, where it is often the dominant vascular plant. In contrast, the species is not as ecologically significant in ombrotrophic sites in the Hudson Bay lowlands as in the Red Lake Peatland. Although reported as fairly frequent in some bog hollows in the Attawapiskat River area (Sjörs, 1963), large expanses of open bog dominated by this species, which are so common in the Red Lake Peatland, have not been reported from the Hudson Bay lowlands.

Outside of these two peatlands, Carex oligosperma has been reported as having a high importance value in kettle-hole "bogs" in northern Michigan (Vitt and Slack, 1975), as frequent to common in kettle-hole "bogs" in northern Minnesota (Wheeler, 1981) and northern Wisconsin (Zimmerman, 1976), and as common in oligotrophic and mesotrophic "bogs" in Newfoundland (Damman, 1964). In contrast, it plays only a minor role in ombrotrophic sites in the Bay of Fundy region (Damman, 1977). In northern Minnesota (Wheeler, 1981), C. oligosperma is often the most important species in the formation of pioneer mats surrounding acid lakes, as well as being the dominant vascular plant in adjacent moss-heath zones; it is replaced by $C$. lasiocarpa var. americana, however, in kettle-hole "bogs" surrounding alkaline lakes (Wheeler, 1981). In northern Michigan (Vitt and Slack, 1975), C. oligosperma and C. lasiocarpa var. americana are also reported as occurring, respectively, in kettle-hole "bogs" surrounding acid and alkaline lakes.

1 Throughout this paper we use bog in the sense of true ombrotrophic conditions; we use "bog" in the sense of Sphagnum-dominated areas that typically have fen characteristics (e.g., peatland-surrounded basin lakes). In Minnesota, for instance, most kettle-hole "bogs" are actually poor fens and tamarack "bogs" often approach rich-fen conditions. 
Carex trisperma is another North American sedge that does not have a closely related counterpart in European peatlands. In Canada, the species extends as far westward as Saskatchewan (Hudson, 1977; Scoggan, 1978); in the United States, the westernmost stations are in western Minnesota (Wheeler, 1981).

In both the Hudson Bay (Sjörs, 1963) and Red Lake areas, Carex trisperma is frequent to common in the field layer of wooded bogs and is essentially absent from open ombrotrophic sites. Furthermore, in both areas it frequently occurs on wooded poorfen islands and somewhat less commonly in wooded rich fen. In black sprucedominated forests in northern Minnesota (Wheeler, 1981) and northern Michigan (Vitt and Slack, 1975) C. trisperma frequently grows together with Sphagnum recurvum var. brevifolium, the former growing in the extensive carpets of the latter. The sedge is reported from forested oligotrophic and mesotrophic "bogs" and swamps in Newfoundland (Damman, 1964) and from forested areas elsewhere (e.g., Gates, 1942; Osvald, 1970; Zimmerman, 1976; Damman, 1977).

Unlike the two Carex species discussed above, both $C$. pauciflora and $C$. paupercula are widely distributed in northern Europe as well as in northern North America (Hultén, 1964). The latter species, often referred to as C. magellanica by European and Canadian authors, is also known from southern South America (Hultén, 1964).

In both the Hudson Bay lowlands (Sjörs, 1963) and the Red Lake Peatland, Carex pauciflora is more widespread and common in poor fen than in bog; it is also reported from poor fen in Alberta (Vitt et al., 1975a). In northern Minnesota (Wheeler, 1981), C. pauciflora is frequently associated with $C$. oligosperma in kettle-hole "bogs" surrounding acid lakes, but it is essentially absent from $C$. lasiocarpa-dominated "bogs" surrounding alkaline lakes. Its presence in Sphagnum-dominated areas elsewhere in North America is well-documented (e.g., Gates, 1942; Drury, 1956; Damman, 1964, 1977; Vitt and Slack, 1975; Zimmerman, 1976; Hudson, 1977).

In northern European peatlands, Carex pauciflora frequently occurs in minerotrophic sites, particularly poor fen (e.g., Sjörs, 1950; Malmer and Sjörs, 1955; Malmer, 1958, 1962; Eurola and Kaakinen, 1978); it also occurs, though much less commonly, in ombrotrophic sites (Sjörs, 1948, 1963; Eurola and Kaakinen, 1978). In Sweden (Sjörs, 1950), as well as in the Hudson Bay (Sjörs, 1963) and Red Lake areas, C. pauciflora is primarily associated with carpets and lawns and is invariably absent from sites having a mud substrate. In northern Sweden (Sjörs, 1950), the species is a common member of parvocariceta (vegetation characterized by plants of medium to low height and with a well-developed bryophyte layer), growing in wet, open sites. Carex pauciflora also occurs in northern Asia (Hultén, 1964) and is reported from the Polesie peatlands in Russia (Kulczynski, 1949).

The presence of Carex paupercula in peatlands in northern North America (e.g., Moss, 1953; Drury, 1956; Sjörs, 1963; Damman, 1964, 1977; Jeglum, 1971; Vitt and Slack, 1975; Zimmerman, 1976; Riley and McKay, 1980; Wheeler, 1981) and northern Europe (e.g., Sjörs, 1950; Sonesson, 1970; Eurola and Kaakinen, 1978) is welldocumented. In the Hudson Bay lowlands (Sjörs, 1963), as in the Red Lake area, the species occurs in both ombrotrophic and minerotrophic sites, with the latter often being wooded poor fen. In northern Minnesota (Wheeler, 1981) and northern Michigan (Vitt and Slack, 1975), C. paupercula occurs frequently in kettle-hole "bogs" surrounding acid lakes but is infrequent in "bogs" surrounding alkaline lakes.

According to Sjörs (1963), Carex paupercula does not generally occur in ombrotrophic sites in Fennoscandia, but it is associated with minerotrophic sites, particularly poor fen. In Sweden (Sjörs, 1950; Malmer, 1962), the species is common only $\mathrm{N}$ of "limes norrlandicus" (the border between the northern and southern coniferous forests, usually drawn along the northern limit for oak), where it occurs most frequently in carpets and mud bottoms.

Although Carex limosa is known only from minerotrophic sites in the Red Lake Peatland, it occurs in both ombrotrophic and minerotrophic sites in the Hudson Bay 
lowlands (Sjörs, 1961, 1963) and northern Fennoscandia (e.g., Sjörs, 1950, 1961, 1963; Malmer and Sjörs, 1955; Malmer, 1962; Eurola and Kaakinen, 1978). The species' absence from bogs in the Red Lake area is of particular interest because, according to Sjörs (1963), the plant has a wider edaphic range on ombrotrophic sites in the Hudson Bay lowlands than in Fennoscandian bogs. It is suspected that a lack of suitable habitats in ombrotrophic areas in the Red Lake mire, notably the absence of bog-pools, has confined $C$. limosa to minerotrophic sites. It cannot be ruled out, however, that site requirements at or near the southernmost limit of the species' range differ from those farther N. Indeed, some species appear to change habitats and niches within their geographical range (Gorham, 1956; Gleason and Cronquist, 1964).

In bogs of the Hudson Bay lowlands (Sjörs, 1961, 1963), Carex limosa ranges from the edges of bog-pools and firm peats, where it is frequent, to Sphagnum fuscum hummocks, where it is occasional. The species is also well-known from poor- and rich-fen sites in the Hudson Bay area, occurring primarily in flarks and at the edges of fen-pools (Sjörs, 1963). In Alberta (Vitt et al., 1975a) C. limosa is a dominant species in flarks of patterned poor fen, and in the Bay of Fundy region (Damman, 1977) it is a species of extreme poor fen. In northern Minnesota (Wheeler, 1981), C. limosa frequently occurs in kettle-hole "bogs" surrounding acid lakes and occasionally in "bogs" surrounding alkaline lakes. The species is also known from kettle-hole "bogs" in northern Michigan (Vitt and Slack, 1975) and northern Wisconsin (Zimmerman, 1976), and it has been reported from "bogs" and fens elsewhere in North America (e.g., Gates, 1942; Moss, 1953; Drury, 1956; Damman, 1964; Osvald, 1970; Jeglum, 1971).

Carex limosa is widely distributed in northern Eurasia (Hultén, 1964) and occurs in all types of peatland from ombrotrophic bog to extreme rich fen (Malmer and Sjörs, 1955). In ombrotrophic areas the species is mainly confined to carpets, mud substrates and the edges of bog-pools (Sjörs, 1963); in minerotrophic sites it occurs over a wide variety of habitats. Carex limosa is a common member of parvocariceta in northern Sweden (Sjörs, 1950) and is also well-known S of "limes norrlandicus" (Malmer, 1962).

SPECIES OCGURRING ON MINEROTROPHIC SITES

Excluding the nine Carex species restricted to disturbed sites and the five species discussed above, 15 carices occur on minerotrophic sites in the Red Lake Peatland. Of the latter, three species, $C$. leptalea, $C$. exilis and $C$. interior, are indigenous to North America and do not have closely related counterparts in European peatlands. A fourth North American species, $C$. cephalantha, is closely related and ecologically similar to the European sedge, C. echinata.

Carex leptalea occurs in moderately rich to extremely rich sites in Newfoundland (Damman, 1964) and Saskatchewan (Jeglum, 1971), and it is an obligate rich-fen indicator in the Hudson Bay (Sjörs, 1963) and Red Lake areas. In northern Minnesota (Wheeler, 1981), the species grows in swamps dominated by Larix laricina and Picea mariana, in mixed conifer-hardwood swamps, and less commonly in open fens. It is also known from other "swampy" areas in North America (e.g., Gates, 1942; Drury, 1956; Vitt and Slack, 1975; Zimmerman, 1976).

Carex exilis occurs primarily along the eastern coast of Canada and the northeastern United States and has only scattered populations W of Michigan (Wheeler and Glaser, 1979; Reznicek and Ball, 1980). It is very local in Minnesota, confined mainly to patterned fens (Wheeler, 1981, 1983); the stations in the Red Lake Peatland are the westernmost in North America (Wheeler and Glaser, 1979).

According to Osvald (1970), Carex exilis is a dominant vascular plant in some eastern North American peatlands, frequently occurring in the transitional zone (poor fen) between ombrotrophic sites and the more nutrient-rich communities of the laggs. The species has been reported as an important vascular plant in kettle-hole "bogs" in northern Michigan (Vitt and Slack, 1975), but it is unknown from this habitat in Minnesota and Wisconsin. Carex exilis is reported from the Hudson Bay lowlands (Sjörs, 
1963; Riley and McKay, 1980) but apparently is not frequent there.

In North America, Carex interior is of widespread occurrence and is known from a wide variety of habitats (Reznicek and Ball, 1980). The species is reported from fens in the Hudson Bay lowlands (Sjörs, 1963) and Saskatchewan (Jeglum, 1971), and it is known from fens, swales and other wet, open places in Minnesota (Wheeler, 1981) and elsewhere (e.g., Damman, 1964; Zimmerman, 1976; Hudson, 1977; McGregor et al., 1977; Reznicek and Ball, 1980).

The taxonomic status of Carex cephalantha has been much debated; consequently, it has been treated differently by various authors (Mackenzie, 1931-1935; Fernald, 1970; Reznicek and Ball, 1980). When narrowly defined, as in Fernald (1970), it is a North American plant that has a closely related counterpart in Eurasia, C. echinata. The latter sedge is well known in northern Eurasian peatlands (e.g., Kulczynski, 1949; Osvald, 1949; Malmer, 1962; Ratcliffe, 1964; Mörnsjö, 1969; Eurola and Kaakinen, 1978). These two taxa appear to be very similar ecologically, and some workers (Reznicek and Ball, 1980) do not treat them as taxonomically distinct. Carex cephalantha is not known from the Hudson Bay lowlands, but it is reported from fens and "bogs" elsewhere (e.g., Damman, 1964; Zimmerman, 1976; Wheeler, 1981).

The 11 remaining Carex species with which we are concerned occur in both North America and Europe, and some are even more widely distributed. Various infraspecific taxa have been recognized for some species but, unless stated otherwise, each species is treated sensu lato in the following discussion.

Sjörs (1963) reported Carex livida and C. lasiocarpa from rich-fen sites in the Hudson Bay lowlands and suggested that they probably also occur in poor-fen sites there. In the Red Lake Peatland, these carices frequent both poor- and rich-fen sites, but C. livida is more frequent in poor fen than is C. lasiocarpa.

Carex lasiocarpa is a circumpolar species with three commonly recognized infraspecific taxa: var. americana in northern North America (Hultén, 1964; Fernald, 1970); var. lasiocarpa in northern Eurasia (Hultén, 1964; Chater, 1980); and var. occultans in extreme eastern Asia (Hultén, 1964). For at least the North American and European entities, they appear to be very similar as regards their ecological requirements.

In the Hudson Bay lowlands (Sjörs, 1961, 1963), Carex lasiocarpa is prominent in rich fen, where it grows in fen-pools and flarks. In both Saskatchewan (Jeglum, 1971) and Newfoundland (Damman, 1964), the species is reported from open mesotrophic sites. And in northern Minnesota (Conway, 1949; Leisman, 1953; Wheeler, 1981), northern Wisconsin (Zimmerman, 1976) and northern Michigan (Vitt and Slack, 1975), C. lasiocarpa occurs commonly in fens and laggs, and it is often the most important plant in the formation of pioneer mats surrounding kettle-hole alkaline lakes, as well as the dominant vascular plant in adjacent moss-heath zones. The species has been reported from fens and "bogs" elsewhere in North America (e.g., Gates, 1942; Moss, 1953; Drury, 1956; Osvald, 1970).

In Eurasian peatlands (e.g., Kulczynski, 1949; Osvald, 1949; Mörnsjö, 1969; Sonesson, 1970; Eurola and Kaakinen, 1978), Carex lasiocarpa occurs in extreme poor to extreme rich fen (Malmer and Sjörs, 1955). In northern Sweden (Sjörs, 1950), it is a common member of magnocariceta (vegetation characterized by tall sedges and grasses and mainly without bryophytes), where it often grows as a dominant in mud bottoms.

Carex livida is essentially an amphiatlantic species (Hultén, 1958) with three commonly recognized infraspecific taxa: the vars. livida, radicaulis (often called grayana, but see Voss, 1966, 1972) and rufinaeformis occur in northern North America (Hultén, 1958; Fernald, 1970); and the var. livida occurs in northern Europe (Hultén, 1958; Chater, 1980). The Hudson Bay (Sjörs, 1963) and Red Lake material is var. radicaulis, which differs from typical var. livida in its acute perigynia and greater height (Fernald, 1970). These two taxa, however, appear to be ecologically similar.

In the Hudson Bay lowlands (Sjörs, 1961, 1963), Carex livida occurs in rich-fen 
sites, growing primarily in fen-pools and flarks; it is also reported from eutrophic sites in Saskatchewan (Jeglum, 1971). In northern Minnesota (Wheeler, 1981, 1983), the species is a regular constituent in upland peatland, occurring most commonly in flarks of patterned fen. The species has also been reported from fens and "bogs" elsewhere in North America (e.g., Drury, 1956; Damman, 1964; Osvald, 1970; Voss, 1972; Zimmerman, 1976).

In northern Europe (e.g., Sjörs, 1950; Sonesson, 1970; Eurola and Kaakinen, 1978), Carex livida occurs in both poor- and rich-fen sites. It is a frequent member of parvocariceta in northern Sweden (Sjörs, 1950), sometimes occurring as a dominant in carpets and on mud substrates; S of "limes norrlandicus" it is only of local occurrence (Malmer, 1962).

According to Hultén (1964), Carex chordorrhiza is a morphologically rather invariable circumpolar species. In both the Hudson Bay (Sjörs, 1963) and Red Lake areas, it occurs widely in minerotrophic sites, such as in fens and ecotone areas between fen and bog, and in both areas it serves as an indicator of poor fen. The species is also reported from poor fen in Alberta (Vitt et al., 1975a), and in Saskatchewan (Jeglum, 1971) it is best known from oligotrophic sites. In northern Minnesota (Wheeler, 1981), the species is frequent in open fens and in kettle-hole "bogs" surrounding acid lakes, and it also occurs, though less commonly, in "bogs" surrounding alkaline lakes. Its presence in fens and "bogs" elsewhere in North America is welldocumented (e.g., Drury, 1956; Damman, 1964; Osvald, 1970; Voss, 1972; Zimmerman, 1976).

In northern European peatlands (e.g., Malmer and Sjörs, 1955; Mörnsjö, 1969; Sonesson, 1970; Eurola and Kaakinen, 1978), Carex chordorrhiza occurs in minerotrophic sites, particularly poor fen. In northern Sweden (Sjörs, 1950), the species is a frequent member of parvocariceta, growing in carpets and on mud substrates; S of "limes norrlandicus" it is occasional in occurrence (Malmer, 1962).

Like Carex chordorrhiza, C. tenuiflora is a morphologically rather invariable circumpolar species (Hultén, 1964). Sjörs (1963) reports $C$. tenuiflora as an obligate rich-fen indicator in the Hudson Bay lowlands, but as mentioned earlier, this does not hold in the Red Lake area, where the plant occurs in both poor- and rich-fen sites. In Saskatchewan (Jeglum, 1971) the species is reported from oligotrophic sites, and in Newfoundland (Damman, 1964) it occurs in mesotrophic sites and along "bog" borders. In northern Minnesota (Wheeler, 1981), C. tenuiflora grows in both open and wooded "bogs" and in fens. It is reported from "bogs" and fens elsewhere in North America (e.g., Drury, 1956; Voss, 1972; Zimmerman, 1976). In Finland (Eurola and Kaakinen, 1978), the species occurs on hummocks in minerotrophic sites.

Unlike the two Carex species just discussed, $C$. canescens is a morphologically variable circumpolar species with several recognized infraspecific taxa (Hultén, 1964; Fernald, 1970). It is widely distributed in northern North America (e.g., Moss, 1953; Drury, 1956; Sjörs, 1963; Damman, 1964; Jeglum, 1971; Zimmerman, 1976; Riley and McKay, 1980; Wheeler, 1981) and northern Eurasia (e.g., Kulczynski, 1949; Osvald, 1949; Malmer, 1962; Mörnsjö, 1969; Sonesson, 1970; Eurola and Kaakinen, 1978), where it occurs in open and wooded minerotrophic sites.

In the Hudson Bay lowlands (Sjörs, 1963), Carex canescens occurs in wooded poor fen. In northern Minnesota (Wheeler, 1981), the species grows in oligotrophic and mesotrophic open "bogs" and conifer swamps, and it is frequently associated with floating peat mats bordering the margins of acid and alkaline kettle-hole lakes, where it sometimes dominates the innermost zone (the "marginal caricetum" of Conway, 1949). The majority of Red Lake material can be referred to var. disjuncta, but because it and var. subloliacea seem to intergrade in the mire, recognition of them seems scarcely warranted here.

In both the Hudson Bay (Sjörs, 1963) and Red Lake areas, Carex brunnescens and $C$. disperma are best known from wooded minerotrophic sites. They are also reported from 
minerotrophic sites - wooded and open - in Finnish peatlands (Eurola and Kaakinen, 1978).

In northern Minnesota (Wheeler, 1981), Carex brunnescens is widespread and abundant in forested places, but it also occurs in thinly wooded sites and clearings. The species is reported from various other areas in North America (e.g., Moss, 1953; Drury, 1956; Damman, 1964; Voss, 1972; Zimmerman, 1976; Hudson, 1977). All Red Lake material is var. sphaerostachya, which differs from typical var. brunnescens in being a somewhat taller plant and more southerly ranging (Hultén, 1964; Fernald, 1970).

According to Dansereau and Segadas-Vianna (1952), reduced light and a constant water table are the conditions most favorable for the best growth of Carex disperma. In northern Minnesota (Wheeler, 1981), this species grows best in shaded places in mesotrophic sites, particularly in wet woodlands and along the mossy banks of streams. It is also reported from elsewhere in North America (e.g., Drury, 1956; Damman, 1964; Osvald, 1970; Jeglum, 1971; Dirschl and Coupland, 1972; Voss, 1972; Zimmerman, 1976; Riley and McKay, 1980).

According to Hultén (1958), Carex buxbaumii is an amphiatlantic species that often shows large gaps between local distributional areas and is morphologically somewhat variable. In both the Hudson Bay (Sjörs, 1963) and Red Lake areas, where the plant is infrequent to occasional, it grows in minerotrophic sites, particularly fen flarks. The species is present in open fens and swales throughout much of Minnesota (Wheeler, 1981), and it has been reported from similar habitats elsewhere in North America (e.g., Damman, 1964; Hultén, 1968; Voss, 1972; Zimmerman, 1976; Hudson, 1977). In Finland (Eurola and Kaakinen, 1978), the species is reported from minerotrophic sites.

Carex diandra, which morphologically is rather invariable, is a circumpolar species that also is reported from the Canary Islands and New Zealand (Hultén, 1964, 1968). It grows in open rich fens in the Hudson Bay lowlands (Sjörs, 1963) and in both open and wooded rich fens in the Red Lake area. In northern Minnesota (Wheeler, 1981), C. diandra is frequent on the margins of floating peat mats surrounding alkaline lakes and in fens. It is reported from fens and "bogs" elsewhere in North America (e.g., Moss, 1953; Damman, 1964; Hultén, 1968; Jeglum, 1971; Voss, 1972; Zimmerman, 1976). In northern Eurasian peatlands (e.g., Kulczynski, 1949; Osvald, 1949; Sjörs, 1950; Eurola and Kaakinen, 1978), the species occurs in minerotrophic fens, particularly fen flarks.

Although Carex rostrata was not reported from the Hawley Lake (Sjörs, 1961) or Attawapiskat River (Sjörs, 1963) areas, it is known from the Kinoje Lakes area in the Hudson Bay lowlands (Riley and McKay, 1980). This species is widespread and common in wetlands throughout Minnesota (Wheeler, 1981), particularly along the margins of soft-water lakes. Its presence in fens and "bogs" in both North America (e.g., Gates, 1942; Drury, 1956; Damman, 1964; Osvald, 1970; Jeglum, 1971; Dirschl and Coupland, 1972; Vitt et al., 1975a; Zimmerman, 1976) and northern Eurasia (e.g., Kulczynski, 1949; Osvald, 1949; Sjörs, 1950; Malmer, 1962; Ratcliffe, 1964; Eurola and Kaakinen, 1978) is well-documented. In northern Sweden (Sjörs, 1950), the species is a frequent member of magnocariceta and sometimes occurs as a dominant on mud substrates. The Red Lake material of this morphologically rather variable circumpolar species is var. utriculata.

Carex pseudo-cyperus is widely distributed in northern North America and northern Eurasia (Hultén, 1964) and, if taken in the wide sense of Kükenthal (1909), it also occurs in the southern hemisphere. The plant grows in a variety of wet places, often rooted in muck, and has been reported from various fens and "bogs" (e.g., Kulczynski, 1949; Sjörs, 1950; Damman, 1964; Mörnsjö, 1969; Voss, 1972; Zimmerman, 1976; Eurola and Kaakinen, 1978; Wheeler, 1981).

Based on the floristic data of Sjörs $(1961,1963)$ and Riley and McKay (1980), the 
quotient of similarity (defined below), for Carex, between the Red Lake Peatland and the interior wetlands of the Hudson Bay lowlands is 73. Carex species restricted to coastal and estuarine habitats in the Hudson Bay area are not considered in the aforementioned computation. Eurola and Kaakinen (1978) list 51 species of Carex from Finnish mires and, using their data, the quotient of similarity, for Carex (sensu lato), between the Red Lake Peatland and Finnish mires is 43. And using the same above data, the quotient, for Carex (sensu lato), between the Hudson Bay lowlands and Finnish mires is 51 .

As given in Table 9, a total of 41 species of Carex are known from the Red Lake and Hudson Bay areas (excluding coastal-estuarine species), 24 of which occur in Finnish mires. Of the 29 Carex species known to occur in the Red Lake Peatland, six are not reported from the Hudson Bay lowlands. And in turn, of the 35 carices reported from the interior wetlands of the Hudson Bay lowlands, 12 are not known from the Red Lake mire. There are 16 Carex species (sensu lato) common to the Red Lake, Hudson Bay and Finnish peatlands.

\section{Comparisons with Peatland Floras Elsewhere}

GENERAL REMARKS

Because peatlands generally develop on areas of gentle slope and poor drainage, their floras are relatively impoverished, especially when compared to floras from mineral-soil areas that are ecologically complex - with diverse topographies and complicated soil catenas. Indeed, whereas only 195 vascular taxa are known from the Red Lake Peatland, over 720 vascular taxa are known from the Grand Rapids-Cohasset area in N-central Minnesota (Wheeler, 1977), an area (somewhat smaller than that of the peatland) that is covered by mixed conifer-hardwood forest and situated ca. $100 \mathrm{~km}$ SE of Upper Red Lake.

The floristic similarity between regions is clearly greater for plant species found in peatlands than for those found on mineral soil and, when peatlands themselves are compared, the cryptogamous floras are generally more similar than the vascular floras (Sjörs, 1959, 1963). But because several problems arise when peatland data are compared, some of which have been discussed by Dansereau and Segadas-Vianna (1952), Damman (1977), Persson and Sjörs (1960) and Sjörs (1963), the results achieved from comparative studies may not be entirely satisfactory. Nevertheless, some of the results of comparative studies of peatlands are indeed enlightening, especially those that reveal floristic differences.

COMPARISON WITH HUDSON BAY LOWLANDS AND NORTHERN FENNOSCANDIA

The physiography and vegetation of the Hudson Bay lowlands, particularly in the Attawapiskat River area (Sjörs, 1963), closely resemble those of the Red Lake Peatland. The similarities between the Hudson Bay lowlands and the peatlands of northern Fennoscandia have been discussed by Sjörs (1963). In all three regions the mires are characterized by ombrotrophic bogs, areas of weak minerotrophy and patterned rich fens. In each mire, the bogs are very poor in species and have Sphagnum spp. conspicuously prominent; the poor-fen areas, which are often adjacent to the ombrotrophic bogs, differ from the bogs in that they harbor a limited number of minerotrophic indicators; and the rich-fen areas abound in markedly minerotrophic species, with Carex spp. and other cyperaceous plants very prominent.

However, there are clearly some geomorphic and floristic differences that exist among the three areas. Probably the most obvious geomorphic difference is that welldeveloped bog-pools, which are so common in ombrotrophic areas in the Hudson Bay lowlands and northern Fennoscandia (Sjörs, 1963), are essentially absent from the Red Lake Peatland. And permafrost, which is associated with certain landscape features in far northern North America (Sjörs, 1959, 1963) and northern Fennoscandia (Moore and Bellamy, 1974), is not present in the Red Lake mire (Griffin, 1977). Finally, the 
presence of wooded islands in patterned fens is a feature apparently confined to North America.

The quotient of similarity is an excellent measure of the floristic affinity between two areas or two types of vegetation and is defined as the number of species shared by two areas times 100 , divided by the mean of the numbers of species for the two areas or

TABLE 9. - Carex species occurring in the Red Lake Peatland and the interior wetlands of the Hudson Bay lowlands

\begin{tabular}{|c|c|c|}
\hline & $\begin{array}{l}\text { Red Lake } \\
\text { Peatland }\end{array}$ & $\begin{array}{l}\text { Hudson Bay }{ }^{1} \\
\text { lowlands }\end{array}$ \\
\hline C. aquatilis* & $\mathrm{X}$ & $\mathrm{X}$ \\
\hline C. aurea & $\mathrm{X}$ & $\mathrm{X}$ \\
\hline C. bebbii & $\mathrm{X}$ & \\
\hline C. brunnescens* & $\mathrm{X}$ & $\mathrm{X}$ \\
\hline C. buxbaumii ${ }^{*}$ & $\mathrm{X}$ & $\mathrm{X}$ \\
\hline C. canescens ${ }^{*}$ & $\mathrm{X}$ & $\mathrm{X}$ \\
\hline C. capillaris*o & & $\mathrm{X}$ \\
\hline C. cephalantha*a & $\mathrm{X}$ & \\
\hline C. chordorrhiza* & $\mathrm{X}$ & $\mathrm{X}$ \\
\hline C. concinna & & $\mathrm{X}$ \\
\hline C. crawei ${ }^{\circ}$ & & $\mathrm{X}$ \\
\hline C. deflexa $a^{\circ}$ & & $\mathrm{X}$ \\
\hline C. diandra* & $\mathrm{X}$ & $\mathrm{X}$ \\
\hline C. disperma* & $\mathrm{X}$ & $\mathrm{X}$ \\
\hline C. exilis & $\mathrm{X}$ & $\mathrm{X}$ \\
\hline C. flava*o & & $\mathrm{X}$ \\
\hline C. gynocrates ${ }^{\circ}$ & & $\mathrm{X}$ \\
\hline C. heleonastes* & & $\mathrm{X}$ \\
\hline C. interior & $\mathrm{X}$ & $\mathrm{X}$ \\
\hline C. lacustris & $\mathrm{X}$ & \\
\hline C. lanuginosa & $\mathrm{X}$ & $\mathrm{X}$ \\
\hline C. lasiocarpa ${ }^{*}$ & $\mathrm{X}$ & $\mathrm{X}$ \\
\hline C. leptalea & $\mathrm{X}$ & $\mathrm{X}$ \\
\hline C. limosa* & $\mathrm{X}$ & $\mathrm{X}$ \\
\hline C. livida* ${ }^{*}$ & $\mathrm{X}$ & $\mathrm{X}$ \\
\hline C. loliacea* & & $\mathrm{X}$ \\
\hline C. media $^{* \circ}$ & & $\mathrm{X}$ \\
\hline C. microglochin* & & $\mathrm{X}$ \\
\hline C. oligosperma & $\mathrm{X}$ & $\mathrm{X}$ \\
\hline C. pauciflora ${ }^{*}$ & $\mathrm{X}$ & $\mathrm{X}$ \\
\hline C. paupercula* & $\mathrm{X}$ & $\mathrm{X}$ \\
\hline C. projecta & $\mathrm{X}$ & \\
\hline C. pseudo-cyperus* & $\mathrm{X}$ & \\
\hline C. rariflora* ${ }^{*}$ & & $\mathrm{X}$ \\
\hline C. rostrata $*$ & $\mathrm{X}$ & $\mathrm{X}$ \\
\hline C. scirpoidea & & $\mathrm{X}$ \\
\hline C. tenera & $\mathrm{X}$ & \\
\hline C. tenuiflora* & $\mathrm{X}$ & $\mathrm{X}$ \\
\hline C. trisperma & $\mathrm{X}$ & $\mathrm{X}$ \\
\hline C. vaginata* & $\mathrm{X}$ & $\mathrm{X}$ \\
\hline C. viridula ${ }^{* b}$ & $\mathrm{X}$ & $\mathrm{X}$ \\
\hline
\end{tabular}

${ }^{1}$ Sjörs, 1961, 1963; Riley and McKay, 1980 (excluded are species restricted to coastal-estuarine sites)

* Species occurring in Finnish mires (Eurola and Kaakinen, 1978)

${ }^{a}$ Considered morphologically and ecologically similar to the European species, C. echinata.

${ }^{b}$ Considered morphologically and ecologically similar to the European species, $C$. oederi.

- Species occurring in Minnesota but not in the Red Lake Peatland 
vegetation types (Sjörs, 1963). The quotient of similarity (Q.S.) for the vascular floras of the Red Lake Peatland and the interior wetlands of the Hudson Bay lowlands is 57; the Q.S. for the bryophyte floras of the two peatlands is 50 (Table 11). While the quotient given for the vascular floras of the two mires is considered realistic, it is suspected that the quotient for the bryophyte floras will increase with future collecting, particularly in the Red Lake area. Indeed, while over 120 bryophyte taxa (excluding species exclusively confined to riverine sites) are reported by Persson and Sjörs (1960) for the Hudson Bay lowlands, only 67 are thus far known from the Red Lake Peatland.

When just the ombrotrophic vascular floras of the Red Lake and Hudson Bay areas are compared, the quotient of similarity is 63. In comparison, Sjörs (1963) reported the Q.S. for the vascular floras of the bogs of the Hudson Bay lowlands and those of northern Fennoscandia as 53. Using the floristic data given by Sjörs (1963), we find that the Q.S. between the vascular bog floras of the Red Lake Peatland and northern Fennoscandia is 17 .

As mentioned earlier, 23 vascular taxa are known from ombrotrophic sites in the Red Lake Peatland (Table 2). In comparison, 34 vascular taxa are known from bogs in the Hudson Bay lowlands, and 23 vascular taxa from bogs in northern Fennoscandia (Sjörs, 1963).

In most cases, a species that is common to ombrotrophic sites in eastern North America and northern Europe is very similar as regards its vegetative morphology and ecology in the two areas (Sjörs, 1963). Sjörs (1963) states, however, that a few taxa present in ombrotrophic bogs in North America have vicariads in northern Europe, with the distinction being not only morphological but ecological as well. Bog plants from the Red Lake Peatland included in this category are Eriophorum spissum, Ledum groenlandicum and Vaccinium vitis-idaea var. minus; the vicariads to these in northern Europe are Eriophorum vaginatum, Ledum palustre and Vaccinium vitis-idaea, respectively (Sjörs, 1963).

Not counting vicarious taxa, four vascular species are common to ombrotrophic sites in the Red Lake, Hudson Bay and Fennoscandian areas; these are given in Table 10. Table 10 also lists 18 vascular species common to bogs in the Red Lake and Hudson Bay areas. Sjörs (1963) reported 15 vascular taxa as common to bogs in the Hudson Bay lowlands and northern Fennoscandia.

Besides the four taxa known from ombrotrophic sites in all three areas, an additional five species out of the 15 taxa common to bogs in the Hudson Bay and northern Fennoscandian areas also occur in the Red Lake Peatland, but in the latter area they are known only from minerotrophic sites; these taxa are Carex limosa, Drosera anglica, Rhynchospora alba, Scheuchzeria palustris and Scirpus cespitosus var. callosus (Table 10). And again, although Eriophorum chamissonis, Nuphar variegatum and Utricularia cornuta are present in bogs in the Hudson Bay lowlands (Sjörs, 1963), they are known only from minerotrophic sites in the Red Lake Peatland (Table 10). As mentioned earlier, it is suspected that a lack of suitable habitats in ombrotrophic areas in the Red Lake mire, such as the absence of bog-pools, has confined some otherwise acid-tolerant species to minerotrophic sites.

In addition to the differences noted above, Andromeda polifolia, Rubus chamaemorus, Vaccinium uliginosum and $V$. microcarpum are frequent to common in bogs in the Hudson Bay lowlands (Sjörs, 1963) but are unknown from the Red Lake Peatland. And Empetrum hermaphroditum, Geocaulon lividum, Kalmia angustifolia and Pinguicula villosa occur occasionally in Hudson Bay bogs (Sjörs, 1963), but they also have not been found in the Red Lake area. Significantly, several of the aforementioned taxa are present in bogs in northern Fennoscandia.

Five taxa that occur in bogs in the Red Lake area, namely Andromeda glaucophylla, Arceuthobium pusillum, Cypripedium acaule, Listera cordata and Monotropa uniflora, are not reported from the Hawley Lake (Sjörs, 1961) or Attawapiskat River (Sjörs, 1963) areas in the Hudson Bay lowlands. However, Riley and McKay (1980) report Andromeda 
glaucophylla and Monotropa uniflora from the Kinoje Lakes area, but it is not clear if they occur on ombrotrophic sites there.

Although we do not possess enough information at present to give a detailed comparison between the bryophyte floras of the Red Lake and Hudson Bay areas, some comments here seem appropriate. Thus far, 47 bryophyte taxa are known to be common to the two areas. Of the 31 bryophytes reported from ombrotrophic sites in the Hudson Bay lowlands (Sjörs, 1963), 20 are known from the Red Lake Peatland (Table $10)$, but we are not certain whether all 20 occur there on ombrotrophic sites.

Some mosses that are of widespread and common occurrence in bogs and poor fens in the Hudson Bay lowlands (Persson and Sjörs, 1960; Sjörs, 1961, 1963), such as Sphagnum balticum and $S$. lindbergii, are unknown from the Red Lake Peatland. And species such as $S$. jensenii, Catoscopium nigritum and Cinclidium stygium, which help to characterize rich fen in the Hudson Bay area, are also unknown from the Red Lake mire. However, several bryophytes occur commonly in both areas and include, among others, the hepatics Cephalozia pleniceps, Cephaloziella elachista, Cladopodiella fluitans, Mylia anomala, and the mosses Aulacomnium palustre, Calliergon stramineum, Campylium stellatum, Dicranum polysetum, D. undulatum, Drepanocladus revolvens, Hypnum lindbergii, Pleurozium schreberi, Polytrichum juniperinum var. affine, Scorpidium scorpioides and several species of Sphagnum. And although Tomenthypnum nitens occurs in fens in both areas, the very striking and sporadically occurring $T$. falcifolium is known only from the Hudson Bay lowlands (Persson and Sjörs, 1960). However, $T$. falcifolium has recently been discovered in northern Minnesota (Wheeler and Glaser, 1982a), and it is presently being searched for in the Red Lake Peatland.

GOMPARISON WITH OTHER PEATLANDS

In Table 11 the floras of several peatlands from North America and northern Europe have been compared with the flora of the Red Lake Peatland. Because many

TABLE 10.-Vascular plants and bryophytes common to the Red Lake Peatland and ombrotrophic bogs of the Hudson Bay lowlands

Vascular plants

Carex limosa *, C. oligosperma ${ }^{\circ}, C$. pauciflora ${ }^{*}, C$. paupercula ${ }^{\circ}, C$. trisperma $^{\circ}$, Chamaedaphne $^{*}$ calyculata $^{\circ}$, Drosera anglica ${ }^{*}$, D. rotundifolia ${ }^{*}$, Eriophorum chamissonis, E. spissum ${ }^{\circ}$, E. virginicum ${ }^{\circ}$, Gaultheria hispidula $^{\circ}$, Kalmia polifolia ${ }^{\circ}$, Larix laricina ${ }^{\circ}$, Ledum groenlandicum ${ }^{\circ}$, Nuphar variegatum, Picea mariana $^{\circ}$, Rhynchospora alba *, Sarracenia purpurea ${ }^{\circ}$, Scheuchzeria palustris *, Scirpus cespitosus var. callosus ${ }^{*}$, Smilacina trifolia ${ }^{\circ}$, Utricularia cornuta, Vaccinium myrtilloides ${ }^{\circ}, V \cdot$ oxycoccos $^{\circ}$, V. vitis-idaea var. minus $^{\circ}$.

Mosses $^{1}$

Aulacomnium palustre *, Calliergon stramineum *, Dicranum flagellare *, D. polysetum ${ }^{*}$, D. undulatum $^{\circ *}$, Pleurozium schreberi ${ }^{\circ *}$, Pohlia nutans ${ }^{\circ *}$, Polytrichum juniperinum var. affine ${ }^{\circ *}$, Sphagnum capillifolium $^{*}, S$. capillifolium var. tenellum ${ }^{*}, S$. cuspidatum ${ }^{*}, S$. fuscum ${ }^{*}, S$. majus ${ }^{*}, S$. papillosum ${ }^{\circ}, S_{\text {. recurvum var. tenue }}{ }^{*}$, S. russowii ${ }^{\circ}$.

Hepatics $^{1}$

Cephaloziella elachista ${ }^{*}$, Cladopodiella fluitans *, Mylia anomala ${ }^{\circ}$, Ptilidium pulcherrimum ${ }^{\circ}$.

\footnotetext{
- Species occurs in ombrotrophic sites in the Red Lake Peatland

* Species occurs in ombrotrophic sites in northern Fennoscandia (Hudson Bay and northern Fennoscandian data from Sjörs, 1961, 1963)

${ }^{1}$ Although the bryophytes marked with an open circle are known from ombrotrophic sites in the Red Lake Peatland, our collections are inadequate to determine whether the remaining ones occur in ombrotrophic bogs or are restricted to minerotrophic sites
} 
vascular plants and bryophytes are common to the two continents and have similar ecological requirements (Sjörs, 1959), such floristic comparisons as attempted in this table may prove profitable, even though not all of the peatlands listed consist of a complex of bogs and patterned fens.

For each comparison in Table 11, the numbers of genera and species of both vascular plants and bryophytes that the two peatlands have in common are expressed as a percentage of the total number of each category recorded for the Red Lake Peatland. Of even greater significance, quotients of similarity for species of vascular plants and bryophytes found in each selected peatland and in the Red Lake mire are also given in the table.

It appears that both the bryophyte and vascular floras of other North American peatlands exhibit about the same degree of floristic similarity to those of the Red Lake Peatland, the mean quotients for six different areas being 44 and 40 , respectively. In contrast, it can be seen that the bryophyte floras of northern Europe and the Red Lake area are more similar than the vascular floras of the two areas, the mean quotients for seven areas being 42 and 17 , respectively.

Although there is not much difference in the quotients for the bryophyte floras of peatlands in North America and northern Europe when compared to the Red Lake Peatland, there is a substantial difference in the quotients for the vascular floras of the

TABLE 11. - Floristic similarities between the Red Lake Peatland and other peatlands in North America and northern Europe. Q.S. = similarity quotient

\begin{tabular}{|c|c|c|c|c|c|c|}
\hline \multirow[t]{2}{*}{ North America } & \multicolumn{3}{|c|}{ Vascular plants } & \multicolumn{3}{|c|}{ Bryophytes } \\
\hline & Gen. & Spp. & Q.S. & Gen. & Spp. & Q.S. \\
\hline $\begin{array}{l}\text { Hudson Bay Lowlands, Canada } \\
\text { Persson and Sjors (1960); } \\
\text { Sjors (1961, 1963); } \\
\text { Riley and McKay (1980) }\end{array}$ & $70 \%$ & $71 \%$ & 57 & $81 \%$ & $70 \%$ & 50 \\
\hline $\begin{array}{l}\text { Saskatchewan, Canada } \\
\text { Jeglum (1971) }\end{array}$ & $61 \%$ & $44 \%$ & 50 & $32 \%$ & $30 \%$ & 43 \\
\hline $\begin{array}{l}\text { Michigan, U.S.A. } \\
\text { Vitt and Slack (1975) } \\
\text { Gates (1942) }\end{array}$ & $\begin{array}{l}58 \% \\
84 \%\end{array}$ & $\begin{array}{l}33 \% \\
50 \%\end{array}$ & $\begin{array}{l}43 \\
43\end{array}$ & $\begin{array}{r}54 \% \\
-\end{array}$ & $\begin{array}{r}49 \% \\
-\end{array}$ & $\begin{array}{l}55 \\
-\end{array}$ \\
\hline $\begin{array}{l}\text { Alaska, U.S.A. } \\
\text { Drury (1956) }\end{array}$ & $50 \%$ & $27 \%$ & 31 & $51 \%$ & $49 \%$ & 47 \\
\hline $\begin{array}{l}\text { Alberta, Canada } \\
\text { Moss (1953) } \\
\text { Vitt et al. (1975a) }\end{array}$ & $\begin{array}{l}39 \% \\
23 \%\end{array}$ & $\begin{array}{l}26 \% \\
13 \%\end{array}$ & $\begin{array}{l}37 \\
22\end{array}$ & $\begin{array}{l}19 \% \\
35 \%\end{array}$ & $\begin{array}{l}18 \% \\
25 \%\end{array}$ & $\begin{array}{l}30 \\
36\end{array}$ \\
\hline Northern Europe & & & & & & \\
\hline $\begin{array}{l}\text { Finland } \\
\quad \text { Eurola and Kaakinen (1978) }\end{array}$ & $62 \%$ & $26 \%$ & 21 & $65 \%$ & $69 \%$ & 49 \\
\hline $\begin{array}{l}\text { Western Soviet Union (Polesie) } \\
\text { Kulczynski (1949) } \\
\text { Sweden. southern }\end{array}$ & $53 \%$ & $16 \%$ & 17 & $38 \%$ & $39 \%$ & 47 \\
\hline $\begin{array}{l}\text { Sweden, southern } \\
\text { Mörnsjö (1969) } \\
\text { Malmer (1962) }\end{array}$ & $\begin{array}{l}36 \% \\
28 \%\end{array}$ & $\begin{array}{l}12 \% \\
11 \%\end{array}$ & $\begin{array}{l}17 \\
17\end{array}$ & $\begin{array}{l}46 \% \\
43 \%\end{array}$ & $\begin{array}{l}40 \% \\
39 \%\end{array}$ & $\begin{array}{l}48 \\
42\end{array}$ \\
\hline $\begin{array}{l}\text { Sweden, northern } \\
\quad \text { Sonesson }(1970)\end{array}$ & $30 \%$ & $12 \%$ & 16 & $51 \%$ & $49 \%$ & 40 \\
\hline $\begin{array}{l}\text { Britain and Ireland } \\
\text { Osvald (1949) }\end{array}$ & $40 \%$ & $13 \%$ & 16 & $49 \%$ & $36 \%$ & 31 \\
\hline $\begin{array}{l}\text { Scotland } \\
\quad \text { Ratcliffe (1964) }\end{array}$ & $34 \%$ & $10 \%$ & 12 & $59 \%$ & $43 \%$ & 35 \\
\hline
\end{tabular}


two regions when compared to the Red Lake area, with the North American floras much more similar to that of Red Lake. It can also be seen that the Red Lake Peatland has a closer floristic affinity, for vascular plants, with the Hudson Bay lowlands than with any other peatland considered here.

Acknowledgments. - We thank Prof. H. E. Wright, Jr., for valuable advice and assistance in the field; Prof. Gerald B. Ownbey for use of the University of Minnesota Herbarium facilities; and Lee Andrew who piloted the helicopter on several of our field surveys. Financial support from the Minnesota Department of Natural Resources (Peat Project) and National Science Foundation grant DEB-7922142 is gratefully acknowledged.

\section{Literature Cited}

Andrus, R. 1974. The Sphagna of New York State. Ph.D. Thesis, State University of New York, Syracuse. 421 p.

Chater, A. O. 1980. Carex, p. 290-323. In: T. G. Tutin (eds.). Flora Europaea. Cambridge University Press, Cambridge, England.

Conway, V. M. 1949. The bogs of central Minnesota. Ecol. Monogr., 19:173-206.

Crum, H. 1976. Mosses of the Great Lakes forest. University of Michigan Herbarium, Ann Arbor, Michigan. $404 \mathrm{p}$.

W. Steere, and L. E. Anderson. 1973. A new list of mosses of North America, north of Mexico. Bryologist, 65:85-130.

Damman, A. W. H. 1964. Key to the Carex species of Newfoundland by vegetative characteristics. Department of Forestry Publication No. 1017. Ottawa, Canada. 39 p.

1977. Geographical changes in the vegetation pattern of raised bogs in the Bay of Fundy region of Maine and New Brunswick. Vegetatio, 35:137-151.

Dansereau, P. And F. Segadas-Vianna. 1952. Ecological study of the peat bogs of eastern North America. I. Structure and evolution of vegetation. Can. J. Bot., 30:490-520.

Dirschl, H. J. And R. T. Coupland. 1972. Vegetation patterns and site relationships in the Saskatchewan River delta. Ibid., 50:647-675.

Drury, W. H., Jr. 1956. Bog flats and physiographic processes in the upper Kuskokwim River region, Alaska. Contrib. Gray Herb. Harv. Univ., 178:1-130.

Du Rietz, G. E. 1949. Huvudenheter och huvudgränser i svensk myrvegetation. Sven. Bot. Tidskr., 43:274-309.

1954. Die Mineralbodenwasserzeigergrenze als Grundlage einer natürlichen Zweigliederung der nord- und mitteleuropäischen Moore. Vegetatio, 5-6:571-585.

Eurola, S. and E. KaAkinen. 1978. Ecological criteria of peatland zonation and the Finnish mire type system. Unpubl. paper. University of Oulu, Finland. $12 \mathrm{p}$.

Fernald, M. L. 1970. Gray's manual of botany, 8th ed., corrected printing. D. Van Nostrand Co., New York. 1632 p.

FinNey, H. R. 1966. Some characteristics of four raised bogs in northern Minnesota: Stratigraphic relationships and mineralogical properties of the inorganic fraction. Ph.D. Thesis, University of Minnesota, Minneapolis. $168 \mathrm{p}$.

Gates, F. C. 1942. The bogs of northern lower Michigan. Ecol. Monogr., 12:213-254.

Glaser, P. H., G. A. Wheeler, E. Gorham and H. E. Wright, JR. 1981. The patterned mires of the Red Lake Peatland, northern Minnesota: Vegetation, water chemistry and landforms. J. Ecol., 69:575-599.

Gleason, H. A. and A. Cronguist. 1964. The natural geography of plants. Columbia University Press, New York. 420 p.

Gorham, E. 1956. On the chemical composition of some waters from the Moor House Nature Reserve. J. Ecol., 44:375-382.

Griffin, K. O. 1975. Vegetation studies and modern pollen spectra from the Red Lake Peatland, northern Minnesota. Ecology, 56:531-546. 1977. Paleoecological aspects of the Red Lake Peatland, northern Minnesota. Can. J. Bot., 55:172-192.

Hale, M. E. and W. L. Culberson. 1970. A fourth checklist of the lichens of the continental United States and Canada. Bryologist, 73:499-543.

Heinselman, M. L. 1963. Forest sites, bog processes, and peatland types in the glacial Lake Agassiz region, Minnesota. Ecol. Monogr., 33:327-374. 
1970. Landscape evolution, peatland types, and the environment in the Lake Agassiz Peatland Natural Area, Minnesota. Ibid., 40:235-261.

Hofstetter, R. H. 1969. Floristic and ecological studies of wetlands in Minnesota. Ph.D. Thesis, University of Minnesota, Minneapolis. $224 \mathrm{p}$.

Hudson, J. H. 1977. Carex in Saskatchewan. Bison Publishing House, Saskatoon, Saskatchewan. 193 p.

Hultén, E. 1958. The amphi-Atlantic plants and their phytogeographical connections. Almqvist and Wiksell, Stockholm. 340 p.

1964. The circumpolar plants. I. Almqvist and Wiksell, Stockholm. 275 p.

1968. Flora of Alaska and neighboring territories. Stanford University Press, Stanford, California. 1008 p.

Jeglum, J. K. 1971. Plant indicators of $p \mathrm{H}$ and water level in peatlands at Candle Lake, Saskatchewan. Can. J. Bot., 49:1661-1676.

Judd, W. S. 1980. Bryophytes of the peat mat at Ponkapoag Pond, eastern Massachusetts, with taxonomic and ecological notes on Sphagnum. Rhodora, 82:563-578.

Kükenthal, G. 1909. Cyperaceae: Caricoideae, p. 1-824. In: A. Engler (ed.). Das Pflanzenreich 38 Heft (IV. 20).

Kulczynski, S. 1949. Peat bogs of Polesie. Mem. Acad. Pol. Sci. Lett. B, No. 15, 1-356.

Leisman, G. A. 1953. The rate of organic matter accumulation on the sedge mat zones of bogs in the Itasca State Park region of Minnesota. Ecology, 34:81-101.

Mackenzie, K. K. 1931-1935. Cariceae. In: North Am. Flora, 18:(1-7), 1-478. New York Botanical Garden, New York. (Parts 1-3 published in 1931, 4-7 in 1935.)

Malmer, N. 1958. Notes on the relation between the chemical composition of mire plants and peat. Bot. Not., 111:274-288.

1962. Studies on mire vegetation in the Archaean area of southwestern Götland (South Sweden). I. Vegetation and habitat conditions on the Äkhult Mire. Opera Bot., 7, No. 1, $1-322$.

AND H. SJörs. 1955. Some determinations of elementary constituents in mire plants and peat. Bot. Not., 108:46-80.

McGregor, R. L. (coord.), T. M. Barkley (ed.) et al. 1977. Atlas of the flora of the Great Plains. Iowa State University Press, Ames. 600 p.

Moore, P. D. and D. J. Bellamy. 1974. Peatlands. Elek Science, London. 221 p.

Mörnsjö, T. 1969. Studies on vegetation and development of a peatland in Scania, south Sweden. Opera Bot., No. 24, 1-187.

Moss, E. H. 1953. Marsh and bog vegetation in northwestern Alberta. Can. J. Bot., 31:448-470.

Osvald, H. 1949. Notes on the vegetation of British and Irish mosses. Acta Phytogeogr. Suec., 26:1-62.

1970. Vegetation and stratigraphy of peatlands in North America. Nova Acta Regiae Societatis Scientarum Upsaliensis, Uppsala, Sweden. 96 p.

Persson, H. And H. Sjörs. 1960. Some bryophytes from the Hudson Bay lowland of Ontario. Sven. Bot. Tidskr., 54:247-268.

Ratcliffe, D. A. 1964. Mires and bogs, p. 426-477. In: J. H. Burnett (ed.). The vegetation of Scotland. Oliver and Boyd, Edinburgh, Scotland. And D. Walker. 1958. The Silver Flowe, Galloway, Scotland. J. Ecol., 46:407-445.

RezniceK, A. A. And P. W. Ball. 1980. The taxonomy of Carex section Stellulatae in North America north of Mexico. Contrib. Univ. Mich. Herb., 14:153-203.

Riley, J. L. And S. M. McKay. 1980. The vegetation and phytogeography of coastal southwestern James Bay. R. Ont. Mus. Life Sci. Contrib., 124:1-81.

Rose, F. 1953. A survey of the ecology of the British lowland bogs. Proc. Linn. Soc. Lond., 164:186-211.

Scoggan, H. J. 1978. The flora of Canada. Part 2. National Museums of Canada, Ottawa. $545 \mathrm{p}$.

Sjörs, H. 1948. Myrvegetation i Bergslagen. Acta Phytogeogr. Suec., 21:1-299.

1950. Regional studies on North Swedish mire vegetation. Bot. Not. Häfte, 2:173-222. 1952. On the relation between vegetation and electrolytes in North Swedish mire waters. Oikos, 2(1950): 241-258.

1959. Bogs and fens in the Hudson Bay lowlands. Arctic, 12:2-19.

1961. Forest and peatland at Hawley Lake, northern Ontario. Natl. Mus. Can. Bull. No. $171,1-31$

1963. Bogs and fens on Attawapiskat River, northern Ontario. Ibid., No. 186, 45-133. 
Sonesson, M. 1970. Studies on mire vegetation in the Torneträsk area, northern Sweden. III. Communities of the poor mires. Opera Bot., No. 26, 1-120.

Spearing, A. M. 1972. Cation-exchange capacity and galacturonic acid content of several species of Sphagnum in Sandy Ridge Bog, central New York State. Bryologist, 75:154-158.

Stotler, R. and B. Crandell-Stotler. 1977. A checklist of liverworts and hornworts of North America. Ibid., 80:405-428.

Tansley, A. G. 1939. The British Isles and their vegetation. Cambridge University Press, London. 930 p.

Vitt, D. H., P. Achuff and R. E. Andrus. 1975a. The vegetation and chemical properties of patterned fens in the Swan Hills, north-central Alberta. Can. J. Bot., 53:2776-2795.

H. Crum and J. A. Snider. 1975b. The vertical zonation of Sphagnum species in hummock-hollow complexes in northern Michigan. Mich. Bot., 14:190-200. AND N. G. Stack. 1975. An analysis of the vegetation of Sphagnum-dominated kettle-hole bogs in relation to environmental gradients. Can. J. Bot., 53:332-359.

Voss, E. G. 1966. Nomenclatural notes on monocots. Rhodora, 68:437-463. 1972. Michigan flora. Part I. Gymnosperms and monocots. Cranbrook Institute of Science, Bloomfield Hills, Michigan. 488 p.

Wheeler, G. A. 1977. Flora of study area. Terrestrial Vegetation and Wildlife Supplement, Draft Environmental Impact Statement, Minnesota Power and Light Company's Proposed Unit 4, Clay Boswell Steam Electric Station. Minnesota Pollution Control Agency, Chap. 2, p. 6-12 and 40-48, and Appendix A, p. 1-32.

1981. A study of the genus Carex in Minnesota. Ph.D. Thesis, University of Minnesota, St. Paul. 501 p.

1983. Carex of northeastern Minnesota: Cook, Lake, St. Louis, and Itasca counties. Mich. Bot., in press.

AND P. H. Glaser. 1979. Notable vascular plants of the Red Lake Peatland, northern Minnesota. Ibid., 18:137-142. AND . 1982a. Tomenthypnum falcifolium in Minnesota. Ibid., 21:66.

AND 1982b. Vascular plants of the Red Lake Peatland, northern Minnesota. Ibid., 21:89-93.

Zimmerman, J. H. 1976. Carex, p. 32-70. In: N. G. Fassett. Spring flora of Wisconsin, 4th ed. Revised by O. S. Thomson. University of Wisconsin Press, Madison.

Submitted 17 May 1982

Accepted 22 September 1982 